
No. 13

\title{
EDUCATION POLICY OUTLOOK IN \\ ESTONIA
}

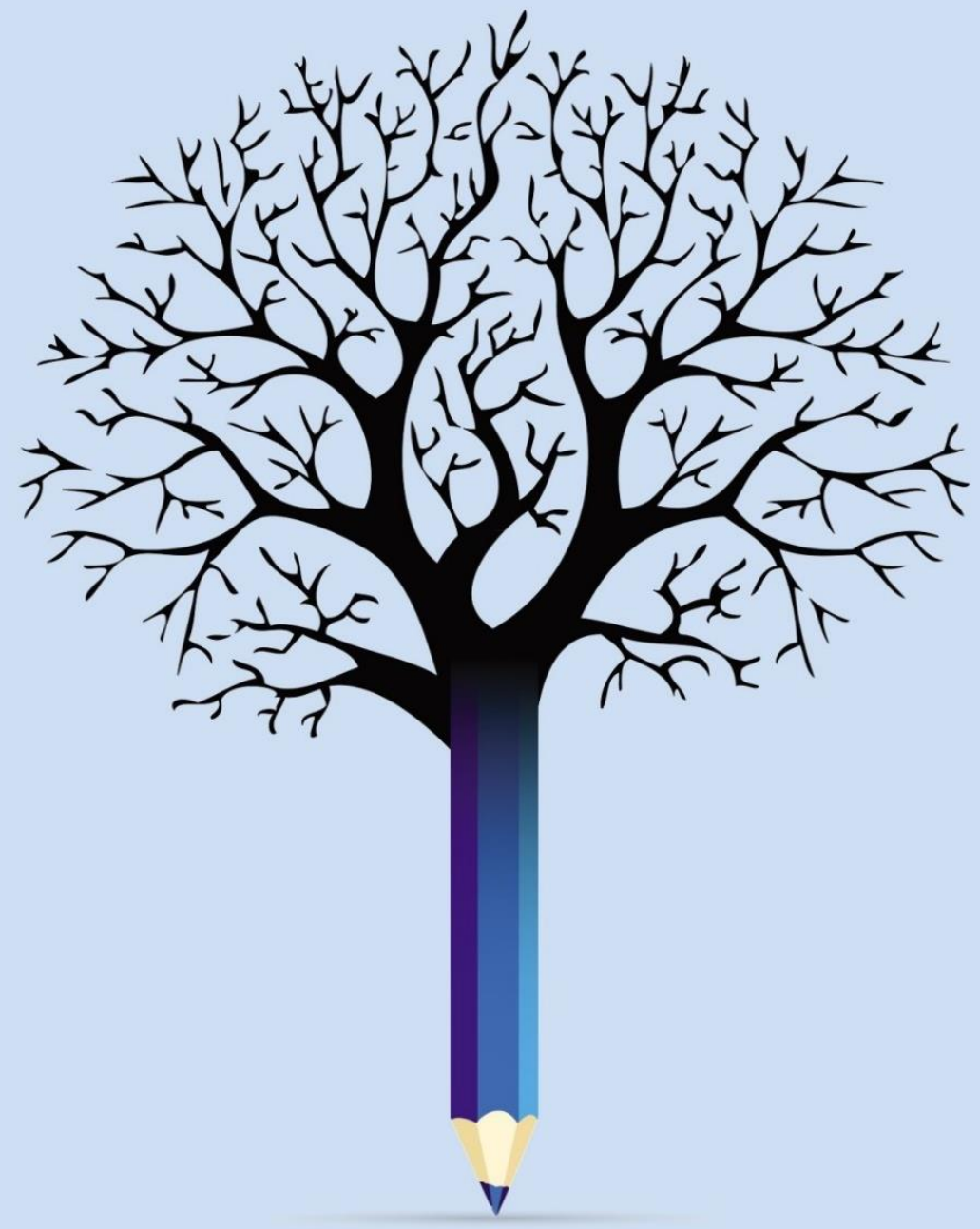




\section{EDUCATION POLICY OUTLOOK}

Note: Most of the content in this profile was written before the COVID-19 outbreak. As such, this document offers insight into pre-existing conditions that may influence the system's responsiveness in the context of the crisis and help inform longer-term efforts to strengthen resilience. Spotlight 1 summarises Estonia's initial responses to the crisis. Its structure is based on work by the Education Policy Outlook in 2020 to support countries in these efforts.

This country policy profile on education in Estonia is part of the Education Policy Outlook series, which presents comparative analysis of education policies and reforms across OECD countries. Building on the OECD's substantial comparative and sectoral policy knowledge base, the series offers a comparative outlook on education policy. This country policy profile is an update of the first policy profile of Estonia (2016) and provides: analysis of the educational context, strengths, challenges and policies; analysis of international trends; and insight into policies and reforms on selected topics. It is an opportunity to take stock of progress and where the education system stands today from the perspective of the OECD through synthetic, evidence-based and comparable analysis.

In addition to country-specific profiles, the series also includes a recurring publication. The first volume, Education Policy Outlook 2015: Making Reforms Happen, was released in 2015. The second volume, Education Policy Outlook 2018: Putting Student Learning at the Centre was released in 2018. Its complement, Education Policy Outlook 2019: Working Together to Help Students Achieve their Potential was released in autumn 2019. Designed for policy makers, analysts and practitioners who seek information and analysis of education policy taking into account the importance of national context, the country policy profiles offer constructive analysis of education policy in a comparative format. Each profile reviews the current context and situation of a country's education system and examines its challenges and policy responses, according to six policy levers that support improvement:

Students: How to raise outcomes for all in terms of 1) equity and quality and 2) preparing students for the future;

Institutions: How to raise quality through 3) school improvement and 4) evaluation and assessment;

System: How the system is organised to deliver education policy in terms of 5) governance and 6) funding.

Some country policy profiles contain spotlight boxes on selected policy issues. They are meant to draw attention to specific policies that are promising or showing positive results and may be relevant for other countries.

Special thanks to the Government of Estonia and, in particular, the Ministry of Education and Research, for its active input during consultations and constructive feedback on this report. We also thank the European Commission for its valuable analytical and financial support for the update of this country policy profile.

Authors: This country policy profile was prepared by Rex Kaplan, Jonathan James, Diana Toledo Figueroa, Christa Rawkins and Clément Dumont in the Policy Advice and Implementation Division, led by Paulo Santiago. Editorial support was provided by Stephen Flynn and Rachel Linden. This profile builds on the knowledge and expertise of many project teams across the OECD's Directorate for Education and Skills, to whom we are grateful. Alexandra Tamasan contributed on behalf of the European Commission Directorate-General for Education and Culture.

Sources: Subject to country participation, this country policy profile draws on OECD indicators from the Programme for International Student Assessment (PISA), the Survey of Adult Skills (PIAAC), the Teaching and Learning International Survey (TALIS) and the annual publication Education at a Glance, and refers to country and thematic studies such as OECD work on early childhood education and care, teachers, school leadership, evaluation and assessment for improving school outcomes, equity and quality in education, governing complex education systems, school resources, vocational education and training, and tertiary education. This profile also draws on information in the OECD Education Policy Outlook National Survey for Comparative Policy Analysis completed in 2016/17 by the Government of Estonia, as well as information provided by the Ministry of Education and Research between 2018 and 2020 as part of the Education Policy Outlook's activities with countries.

Most of the figures quoted in the different sections refer to Annex B, which presents a table of the main indicators for the sources used throughout the country policy profile. Hyperlinks to the reference publications are included throughout the text for ease of reading, and also in the References and further reading section, which lists both OECD and non-OECD sources.

More information is available from the OECD Directorate for Education and Skills (www.oecd.org/edu) and its web pages on the Education Policy Outlook (www.oecd.org/edu/policyoutlook.htm).

In the context of the coronavirus (COVID-19) pandemic, some information is provided about initial responses. 


\section{2 | No. 13 - EDUCATION POLICY OUTLOOK IN ESTONIA}

\section{TABLE OF CONTENTS}

\section{Highlights}

Equity and quality:

Comparatively stronger, but also some gaps to be tackled

Preparing students for the future

Need to promote positive labour market outcomes for all

School improvement

Sustained efforts to raise the status of teachers and school leaders

Evaluation and assessment

Strengthening a culture of evaluation and feedback

Governance

A highly decentralised system evolving in a context of demographic change

Funding

Ensuring resources sustainability for the education system

Annex A: Structure of Estonia's education system

Annex B: Statistics

References and further reading

Notes

Figures

Figure 1. Trends and comparative performance of 15-year-olds in reading, PISA 2018

Figure 2. Evolution of secondary and tertiary attainment among 25-34 year-olds, 2000-18

Figure 3. Selected equity and quality indicators for Estonia, PISA $2018 \quad 10$

Figure 4. Percentage of 18-24 year-olds in education and not in education, by work status, 2018

Figure 5. The learning environment according to students, PISA 2018

Figure 6. Percentage of students in schools where the principal reported assessments of students in national modal grade for 15year-olds, PISA 2015

Figure 7 Percentage of decisions taken at each level of government for public lower secondary schools (2017)

Figure 8. Annual expenditure per student (2016) and recent trends, by level of education

Spotlights

Spotlight 1.The Estonian education system's initial response to the COVID-19 pandemic 4 Spotlight 2. Key policies, challenges and previous OECD recommendations for Estonia 6 Spotlight 3. The European Union perspective $\quad 8$ Spotlight 4. Aligning Estonia's education system with the future: $\quad 13$ Spotlight 5. School consolidation as a priority in Estonia 20 


\section{3 | No. 13- EDUCATION POLICY OUTLOOK IN ESTONIA}

\section{HIGHLIGHTS}

\section{Estonia's educational context}

Students: Estonia continues to outperform other countries in overall PISA performance despite relatively low expenditure on education. In PISA 2018', Estonia was among the top performers in all three domains assessed. Students' socioeconomic status also had the lowest impact on reading performance in the OECD, explaining $6.2 \%$ of the variance (OECD average: $12.0 \%$ ). Performance in reading and mathematics have increased steadily since Estonia's first participation in PISA in 2006. Participation in early childhood education and care (ECEC) has also increased over time; enrolment rates for 3-year-olds are above the OECD average. Upper secondary and tertiary attainment rates are also above the OECD average, and tertiary attainment rates have increased in recent years. Adults in Estonia outperformed the OECD average in literacy and numeracy, as measured by the OECD Survey of Adult Skills (PIAAC) in 2012.

Institutions: Estonia has made significant efforts to strengthen digital skills and inclusive education among teachers, as well as increasing their wages in recent years. In TALIS 2018, the share of teachers that felt their profession was valued in society had almost doubled since TALIS 2013. The disciplinary climate in schools, as reported by students in PISA 2018, is also among the most favourable in the OECD and has increased across PISA cycles. Estonia has comprehensive procedures for system-level evaluation, drawing on data from external and internal evaluations at different levels of the system.

System: In Estonia, schools have a large degree of autonomy. The state sets national standards and establishes principles of education funding, state supervision and quality assessment. While most pre-primary and general schools are owned and run by the municipalities, most vocational schools are state-owned. Overall expenditure on education (measured in terms of share of gross domestic product (GDP) or in USD per student) is relatively low compared to other OECD countries, although Estonia invests an above average proportion of its resources on ECEC and has increased spending on higher education.

\section{Key pre-existing policy issues}

While Estonia's performance and equity levels in PISA 2018 were among the highest in the OECD, some gaps in learning opportunities persist that need to be addressed. Estonia also needs to continue strategically developing the supply of skills in the labour market, for example, with the development of up-to-date skills, including for a digital transformation. Increasing the attractiveness of vocational education and training (VET) to graduates from compulsory education will involve raising students' awareness of the opportunities VET offers, as well as ensuring more successful transitions from initial VET. To improve completion in higher education, Estonia could consider reducing the cost of part-time study, as this may be more suitable for some students. At the school level, with an ageing teaching workforce, attracting qualified candidates to the profession will be a priority going forward. Estonia has made many efforts to consolidate its school network in the context of demographic change, but progress in this area has been uneven across municipalities. Ensuring continued funding for activities currently supported by EU funding and increasing the level of private non-household funding in higher education are also key issues.

\section{Box 1. Strengthening adaptability and resilience in the context of COVID-19 (see Spotlight 1)}

Early evidence suggests that pre-existing resources in the education system facilitated areas of Estonia's initial response. Ongoing recent efforts to strengthen digital skills in students, teachers and other adults, and to enhance the digital infrastructure of the education system likely facilitated the switch to online learning. In particular, Estonia had key tools and supports in place, such as school management platforms, digital resource banks and a team of educational technologists enabling educational actors to mobilise resources already familiar to them. As Estonia works to balance short-term responsiveness with longer-term strategic aims, priorities will evolve. For example, Estonia can continue strengthening the targeted monitoring of the ongoing response through system-level monitoring mechanisms and support collaborative efforts at an international level. Also, while much of the key information and resources available to students and families has been translated into Russian and English, given the specific equity concerns facing Russian-speaking and immigrant students, further targeted supports may be required. 


\section{Spotlight 1.The Estonian education system's initial response to the COVID-19 pandemic}

On 11 March 2020, the World Health Organisation declared the coronavirus (COVID-19) outbreak a global pandemic. Education systems across the world have felt the force of the crisis as confinement measures triggered widespread closures of education institutions. On 13 March, Estonia announced the closure of all educational institutions except kindergartens, from 16 March 2020. A gradual reopening was scheduled from 15 May. In light of the work of the Education Policy Outlook in 2020 in the context of this pandemic, this spotlight offers an insight into the system's initial readiness and responses across five key areas.

1. Ensuring continued access to learning and smooth educational pathways: The switch to distance learning saw a considerable increase in the use of digital platforms, including eSchool (2002), a school management service already used by $85 \%$ of schools, and $\mathrm{E}$ Schoolbag (2016), which hosts educational resources quality-reviewed by subject experts. Estonia also launched a platform to promote distance learning opportunities for adults. From early April, weekly, televised lessons supported students in managing their learning from home. Upper secondary school-leaving examinations were postponed; it was decided that students would sit two examinations at least two weeks after schools reopen and these students would be prioritised when contact teaching resumes. For vocational programmes, flexibility would be provided to run courses and examinations during the summer, at the agreement of all parties. The OECD reported that Estonia had been able to offer career guidance remotely when it was perhaps more valuable than ever. Examinations at the end of lower secondary education were cancelled; students would graduate according to annual grades. For entrance examinations to universities and upper secondary schools, institutions would need to seek flexible solutions, including online examination. Results from the Children's Advisory Panel's survey of 10-18 year-olds indicated that students in Estonia had an aboveaverage level of satisfaction with home learning compared to the other seven countries participating in the survey. Estonia also had the highest share of students who reported that during school closures, they had good access to the internet (73\%) and to school systems (69\%).

2. Strengthening the internal world of the student: To allow students to have meaningful school holidays despite social distancing measures, the Ministry of Education and Research (MER), in cooperation with two media organisations, launched a website offering a range of activities and videos.

3. Collecting, disseminating and improving the use of information about students: The MER issued guidance for student assessment during closures: teachers should not use numerical assessment during the first two weeks, prioritising formative verbal feedback. As distance learning would continue, a virtual development interview with students and parents was recommended. In terms of monitoring, both the Innove Foundation (2003) and the Information Technology Foundation for Education (HITSA, 2013) collated feedback from schools, teachers and parents to inform recommendations for future practice.

4. Providing targeted support and interventions for vulnerable children: Schools for students with special educational needs (SEN) would open according to need and at their discretion. Estonia's network of Pathfinder Centres (2014), regional services offering support and counselling to children with SEN and their families, switched to remote services, including phone or video counselling. When schools reopen, those students finding distance learning more challenging would be prioritised for contact teaching.

5. Harnessing wider support and engagement at local and central level: HITSA and Innove started running regular webinars for teachers, school leaders and parents to support distance education and several Facebook online communities were put in place. Estonia's team of educational technologists started providing remote support to teachers, parents and principals; new specialists were recruited to meet demand. Estonia has long supported Ed-Tech companies, many of whom started providing services to schools and families for free. Several joined an international collaborative, offering remote learning solutions to countries across the world. This is part of Estonia's Education Nation outreach work which, during the pandemic, included a series of webinars sharing Estonia's best practices in remote learning with the world.

\begin{tabular}{|c|c|c|c|c|c|}
\hline & Selected indicators of system readiness (OECD) & Estonia & Average & Min & Max \\
\hline \multicolumn{6}{|c|}{ Students' readiness (according to students' self-reports in PISA 2018) } \\
\hline 1 & Index of self-efficacy & -0.03 & 0.01 & -0.61 & 0.36 \\
\hline 2 & $\begin{array}{l}\text { Percentage of students in disadvantaged schools with access to a } \\
\text { computer at home that they can use for school work }\end{array}$ & $85.0 \%$ & $81.5 \%$ & $23.5 \%$ & $96.5 \%$ \\
\hline \multicolumn{6}{|c|}{ Teachers' readiness (according to lower secondary teachers' self-reports in TALIS 2018) } \\
\hline 3 & $\begin{array}{l}\text { Percentage of teachers with a high level of need for professional } \\
\text { development related to ICT skills for teaching }\end{array}$ & $19.2 \%$ & $17.7 \%$ & $5.3 \%$ & $39.0 \%$ \\
\hline 4 & $\begin{array}{l}\text { Percentage of teachers agreeing that most teachers in the school provide } \\
\text { practical support to each other when applying new ideas }\end{array}$ & $78.1 \%$ & $77.9 \%$ & $64.7 \%$ & $86.5 \%$ \\
\hline
\end{tabular}

Note: The information presented in this spotlight covers key measures announced or introduced before 04 May 2020. 


\section{KEY TRENDS IN PERFORMANCE AND ATTAINMENT}

In PISA 2018, Estonia scored 523 points on average in reading; this was significantly above the OECD average of 487 points and makes Estonia one of the top performers in reading among OECD countries. Estonia's PISA reading performance has increased steadily across PISA cycles. Estonia's score was also above the OECD average across different age groups in the Survey of Adult Skills (PIAAC) 2012.

Figure 1. Trends and comparative performance of 15-year-olds in reading, PISA 2018
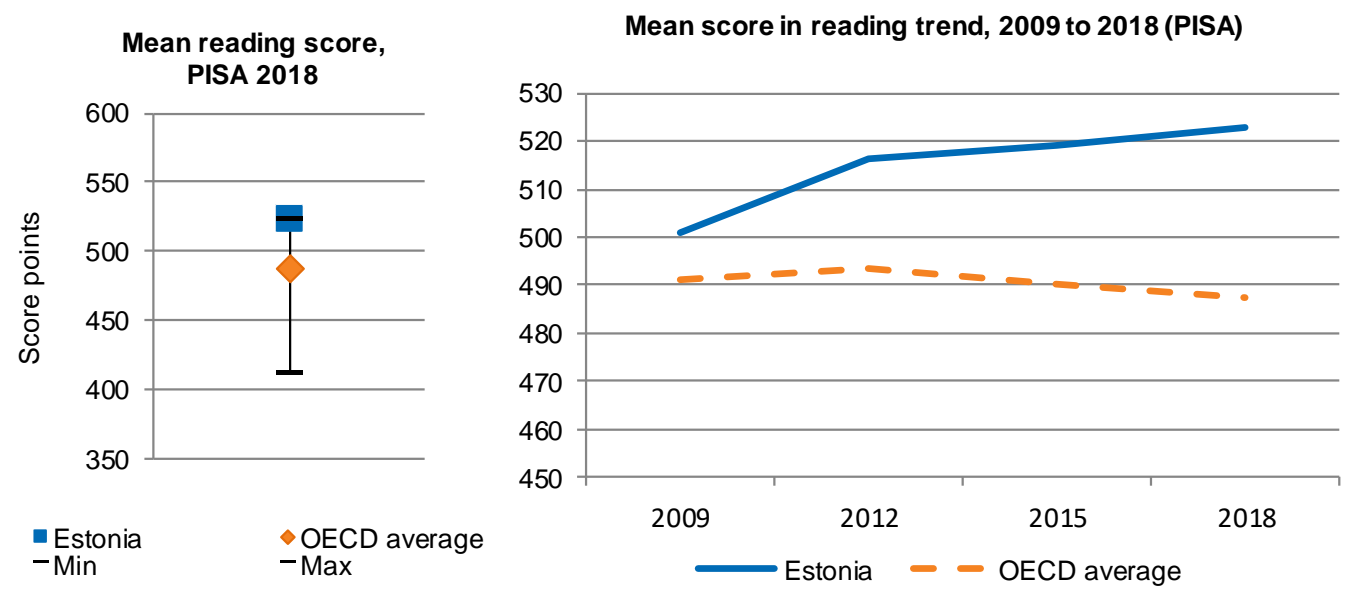

Note: "Min"/"Max" refer to OECD countries with the lowest/highest values

Source: OECD (2019), PISA 2018 Results (Volume l): What Students Know and Can Do, PISA, OECD Publishing, Paris, https://doi.org/10.1787/5f07c754-en

Between 2000 and 2018, there has been an overall decline in the share of 25-34 year-olds in Estonia with at least upper secondary attainment, although this has stabilised in recent years. In 2018 , some $87.9 \%$ of 25 -34 year-olds had attained at least upper secondary education; this is above the OECD average. At the same time, tertiary attainment among 25-34 year-olds increased between 2005 and 2018 at a rate close to the OECD average. In $2018,43.6 \%$ of adults aged $25-34$ had completed tertiary education, compared to an OECD average of $44.3 \%$.

Figure 2. Evolution of secondary and tertiary attainment among 25-34 year-olds, 2000-18

Percentage of 25-34 year-olds with at least upper secondary attainment

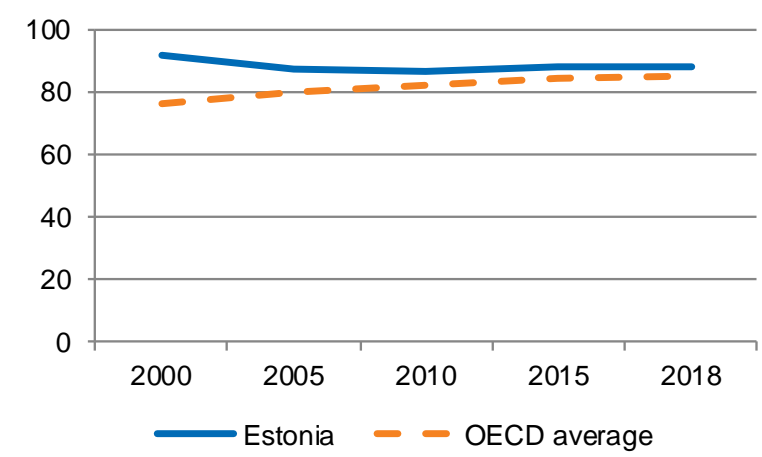

Percentage of 25-34 year-olds with tertiary attainment

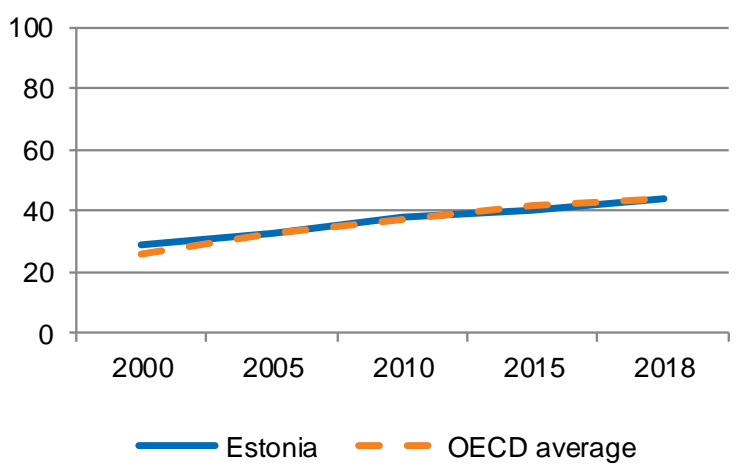

Source: OECD (2019), Education at a Glance 2019: OECD Indicators, OECD Publishing, Paris, https://doi.org/10.1787/f8d7880d-en. 


\title{
Spotlight 2. Key policies, challenges and previous OECD recommendations for Estonia
}

\author{
Main policies from Estonia included in this \\ country policy profile \\ Key challenges identified and \\ recommendations previously provided by \\ the OECD to Estonia
}

\section{STUDENTS}

- Amendments to the Basic and Upper Secondary School Act $(2010,2017)$

- Amendments to the Pre-school Child Care Institutions Act $(2014,2017)$

- Vocational Educational Institution Act (2013)

- Labour Market and Education Cooperation Programme (2015)

- $\quad$ Adult Education Act (2015)

- Amendments to the Professions Act (2015)

- The Estonian Lifelong Learning Strategy 2020 (2014)

- Amendments of the Higher Education Act (2019)
Key challenges identified [2015, 2016, 2018, 2019]: According to previous OECD analysis, despite the progress made, the limited Estonian-language skills of many Russian-speaking students limited their choice of pathways beyond compulsory education. Although Estonia has made significant efforts to integrate students with special education needs (SEN) into mainstream schools, the $\mathrm{OECD}$ has highlighted remaining challenges in this area. One report found that many parents of SEN students preferred special schools, believing mainstream schools were ill-equipped to meet their children's' needs. The OECD also identified a need to improve VET completion rates and to make VET more attractive, particularly for higher achievers.

Summary of previous related OECD recommendations: The OECD recommended that Estonia provide financial support to school owners to increase the number of hours of Estonianlanguage classes for Russian-speaking students and to support SEN students in mainstream education. The OECD advised the government to earmark this funding and monitor its impact. To address dropout rates in VET, the OECD recommended linking VET school funding to completion rates. The OECD also recommended developing a multi-dimensional strategy to improve transitions from initial VET to higher level VET programmes and higher education. Furthermore, the OECD recommended setting targets for work-based learning in enterprise to improve transitions to the labour market.

\section{INSTITUTIONS}

- Increasing Teachers' Salaries (2013)

- New competence-based career structure and teacher certification process (2014)

- Digital competency assessments (2019)

- Digital Mirror (2018)

- New professional standards for teachers (2020)
Key challenges identified [2015, 2017, 2018, 2019]: Although the OECD identified an oversupply of teachers, Estonia's ageing teacher workforce identified at the time of the analysis implied a need to ensure the continuous entry of new talent into the profession. The OECD also found that the position of school leader lacked a distinct status from the role of the teacher, and that there was no systematic mechanism for giving school leaders professional feedback. While Estonia had introduced a new competence-based career structure, there were limited incentives for teachers to engage with it. The OECD also identified a need for an external check on schools' internal assessment processes to ensure greater consistency and comparability.

Summary of previous related OECD recommendations: To raise the status and attractiveness of the teaching profession, the OECD recommended strengthening incentives for newly qualified teachers. At the same time, there was room to make 


\begin{tabular}{|c|c|}
\hline & $\begin{array}{l}\text { entry to initial teacher education more selective to improve the } \\
\text { quality of those entering the profession. The OECD also } \\
\text { recommended using the new competency-based career } \\
\text { structure as the basis for a mandatory periodical teacher } \\
\text { certification process. It also recommended further aligning the } \\
\text { new career structure with teacher appraisal and professional } \\
\text { development. In addition to this, the OECD recommended } \\
\text { developing a distinct salary scale and appraisal procedures for } \\
\text { school leaders. To improve the consistency of school self- } \\
\text { evaluation, the OECD also recommended extending current } \\
\text { external evaluation procedures to conduct individual school } \\
\text { evaluations in cases where there were quality concerns. As an } \\
\text { alternative, Estonia could introduce an audit system for school- } \\
\text { based internal evaluation }\end{array}$ \\
\hline \multicolumn{2}{|c|}{ SYSTEM } \\
\hline $\begin{array}{l}\text { - School Network Programme (2014-2020) } \\
\text { - Higher education reform: means-tested financial } \\
\text { support for students, free education (2013) } \\
\text { - New funding model for higher education (2017) } \\
\text { - } \quad \text { New funding model for vocational education and } \\
\text { - Hraining (2018) } \\
\text { - } \text { pubher Education Act aniversities (2019) } \\
\text { - Estonian Lifelong Learning Strategy (2014 - 2020); } \\
\text { Smart and Active Estonia } 2035(2021-24)\end{array}$ & $\begin{array}{l}\text { Key challenges identified }[2016,2017,2018,2019] \text { : The } \\
\text { OECD found that the distribution of education responsibilities } \\
\text { between the state and the municipalities was complex and } \\
\text { unclear, and that municipal and state schools were often in } \\
\text { competition. In addition, many smaller municipalities had } \\
\text { limited administrative capacity. While efforts had been made to } \\
\text { consolidate Estonia's school network in the context of a } \\
\text { demographic decline, progress had been slow and there were } \\
\text { still inefficiencies within the system. } \\
\text { Summary of previous related OECD recommendations: } \\
\text { The OECD supported Estonia's movement towards a system } \\
\text { in which municipalities provide pre-primary, primary, and lower } \\
\text { secondary education, and the state provides upper secondary } \\
\text { education. To facilitate the further consolidation of the school } \\
\text { network, the OECD recommended developing the planning } \\
\text { capacity of municipalities through inter-municipal collaboration. } \\
\text { This could take the form of joint planning, co-management of } \\
\text { basic schools and the sharing of resources. It also } \\
\text { recommended specifying a minimum threshold for class sizes } \\
\text { to promote further consolidation. }\end{array}$ \\
\hline \multicolumn{2}{|c|}{$\begin{array}{l}\text { Note: The information on key challenges and recommendations contained in this spotlight draws from a desk-based compilation from } \\
\text { previous OECD publications (subject to country participation). The spotlight is intended for exploratory purposes to promote policy } \\
\text { dialogue and should not be considered an evaluation of the country's progress on these recommendations. Causality should not be } \\
\text { inferred either: while some actions taken by a country could correspond to previous OECD recommendations, the OECDD } \\
\text { acknowledges the value of internal and other external dynamics to promote change in education systems. } \\
\text { Main sources: } 2012,2015,2017 \text { : Economic Survey of Estonia; } 2015,2018,2019 \text { : Education Policy Outlook Comparative Report; } \\
\text { 2016, 2018: Education at a Glance; 2016: OECD Reviews of School Resources of Estonia; 2019: Vocational Education and Training } \\
\text { in Estonia. }\end{array}$} \\
\hline
\end{tabular}




\section{Spotlight 3. The European Union perspective}

\section{Estonia's education and training system and the Europe 2020 Strategy}

- In the European Union's growth and employment strategy, Europe 2020, education and training is recognised as a key policy area in contributing to Europe's economic growth and social inclusion. The European Union set a two-fold target in education by 2020: reducing the rates of early school-leaving below $10 \%$ and reaching at least $40 \%$ of $30-34$ yearolds completing tertiary or equivalent education. Countries set their own related national targets. The Europe 2020 goals are monitored through the European Union's yearly assessment of the main economic and growth issues. In July 2019, the Council of the European Union adopted country-specific recommendations, calling on Estonia to "address skills shortages and foster innovation by improving the capacity and labour market relevance of the education and training system".

- The European Semester Country Report 2020 identified a number of key issues for Estonia in education and training:

- Although the education and training system generally performs well, important challenges remain.

- Estonia tops the 2018 PISA ranking of EU countries in mean performance in reading, mathematics and science, and has the lowest shares of low achievers in all three tested domains. At the same time, Estonia also has one of the most equitable education systems in the EU, with the smallest impact of socio-economic background on students' performance. Estonia has above-average results when it comes to the population's digital skills and has made significant progress in expanding the availability of digital learning resources and information technology learning. However, these performances are affected by a rate of early school-leaving that has not seen consistent improvement and which remains too high given the demographic and the economic context.

- The emerging teacher shortages and the unattractiveness of the profession risk affecting the quality of education. Half of all teachers in primary and secondary education are over 50 years old and almost one in five teachers is over 60. Many schools already report difficulties in hiring teachers in specific subjects. However, teacher education programmes are generally undersubscribed and, according to TALIS 2018, only $26.4 \%$ of Estonian teachers believe that their profession is valued in society (see "School Improvement"). An above-average share of teachers report a need for additional continuing professional development.

- The performance gap between Estonian and Russian-medium basic schools persists, worsening regional disparities and hindering mobility across the country because of the language barrier. The proficiency in Estonian of students with a different mother tongue remains well below the national target of $90 \%$.

- The reported skills shortages suggest that the link with the labour market remains a challenge.

- Estonia is below the EU average regarding the number of students attending vocational programmes. The share of apprenticeship students has increased, but it was still only at $6.5 \%$ in 2018. Measures are under way to improve the quality of work-based learning and to further strengthen career counselling and related services offered to young people.

- Although tertiary educational attainment in the 30-34 age group was above the EU average in 2019 (46.2\% against $41.6 \%$ ), the rate may worsen if the high dropout rates from higher education and falling enrolment rates persist. The gender gap in tertiary attainment is significant. Graduates' competences are insufficiently aligned with labour market needs. The actual number of graduates in science, technology, engineering and mathematics is insufficient to meet the needs of the labour market. The funding system, accompanied by incentives to increase enrolments in certain study fields, aims to increase the quality and labour market relevance of higher education, but impact is yet to be seen.

- The participation of adults in learning continued to increase in 2019 and is significantly above the EU average but still does not meet the changing needs of the labour market. The public training provision for adults relies largely on the EU Structural Funds. Since autumn 2019, quality evaluations of institutions providing non-formal training following the requirements set by the Adult Education Act (2015) have started. 


\section{EQUITY AND QUALITY: COMPARATIVELY STRONGER, BUT ALSO SOME GAPS TO BE TACKLED}

Since its first participation in PISA in 2006, Estonia has outperformed most other OECD and non-member countries both in overall performance and on indicators of equity. Estonia's performance in reading and mathematics increased steadily in the period 2006-2018, although its performance in science broadly remained stable. In PISA 2018, Estonia was among the top performers in all three assessments. Estonia also had the smallest share of low performers in reading among OECD countries, with $11.1 \%$ of students achieving below proficiency level 2, compared to an OECD average of $22.6 \%$. Its share of high performers, at $13.9 \%$, was among the highest in the OECD, where the average was $8.7 \%$. In addition, students' socio-economic status had the lowest impact on reading performance in the OECD, explaining $6.2 \%$ of the variance; well below the OECD average of $12.0 \%$.

Early childhood education and care (ECEC) policies can increase the equity of education systems. In the International Early Learning and Child Well-being study (IELS, 2020), children in Estonia displayed strong self-regulation and social-emotional skills. Children's early learning skills and participation in ECEC were also less strongly associated with their socio-economic background compared to the other two participating countries. Integrated programmes, which include education and childcare services, exist nationally. They offer a formal curriculum delivered by qualified teachers. ECEC institutions are divided into crèche (lastesõim) for children up to 3 years old and pre-school (lasteaed) for children up to 7 years old. Since 2014, all children aged between 1.5 and 7 years are legally entitled to pre-primary education. Estonia has comparatively high ECEC participation rates, and these have increased over time. In 2017, Estonia's enrolment of 2-year-olds (73\%) and 3-year-olds (91\%) in ECEC was higher than the respective OECD averages of $62 \%$ and $79 \%$. Similarly, during the same year, over $80 \%$ of children aged 2 and under spent more than 30 hours per week in ECEC, compared to an EU average of $40-50 \%$. A 2018 EU report had also identified smaller inequalities in access to ECEC, compared to other EU countries. Estonia has undertaken efforts to address a shortage of places in some urban municipalities (see "Funding").

According to OECD evidence, some system-level policies can favour equity, such as a longer period of compulsory education, delayed tracking, managed school choice and grade repetition. Compulsory education in Estonia begins at age 7 and ends at the end of basic school, usually at the age of 16 . Students are first tracked into different educational pathways at the age of 16, which is the most common age across OECD countries. In PISA 2015, only 4\% of 15-year-olds in Estonia reported that they had repeated a grade in either primary or post-primary education, compared to the OECD average rate of $11.3 \%$. International evidence suggests that school choice policies can lead to less equitable outcomes if not well managed. In Estonia, increased school choice has been accompanied by measures to provide additional information to parents and students to inform their choice of school and does not appear to have led to high levels of segregation in comparative terms. In PISA 2018, Estonia scored comparatively higher in the index of academic inclusion (80.8) and the index of social inclusion (79.5), compared to the OECD average values of 70.8 and 76.1 , respectively.

Data from PISA 2018 points, however, to some performance gaps. Students in Russian²-medium schools scored on average 42 points less than students in Estonian-medium schools in reading and science, and 29 points less in mathematics. These performance gaps, alongside poor acquisition of the Estonian language, may impact Russianspeaking students' study options at the end of basic school, as well as their opportunities to enter higher education or the labour market. However, in the IELS 2020, Russian-speaking children scored higher than Estonian-speaking children on a range of early learning measures, suggesting that these disparities do not exist at every level of the education system. Estonia has implemented policies to improve the Estonian-language proficiency of Russian-speaking students (see "Recent policies and practices"). Gaps also exist in Estonia for students from immigrant backgrounds, who had lower performance in reading compared to their peers in PISA 2018. The performance gap was of 35 points, after accounting for gender and students' and schools' socio-economic profile. Across OECD countries, this difference was of 24 points. Furthermore, performance gaps exist between boys and girls. Boys scored on average 31 points less than girls in reading. Boys' comparatively low achievement can affect learning outcomes at the end of compulsory education, as well as their study options upon graduation.

\section{Key strengths and challenges in equity ad quality (pre-crisis analysis)}

\section{Key strengths}

- PISA performance is among the highest in the OECD, with an increasing proportion of high performers, and socioeconomic status had the lowest impact on students' reading performance in the OECD.

- ECEC in Estonia has been a policy priority, both in terms of access and quality.

- Several system-level policies in place promote equity.

\section{Key challenges}

- Estonia needs to continue efforts to increase performance across disciplines (including for science, where it has remained unchanged), while bridging gaps for students in Russian-speaking schools or from immigrant backgrounds, or gaps between girls and boys. 


\section{Recent policies and practices}

Estonia has implemented a number of measures to improve Estonian-language skills among Russian- speaking students. The Language Immersion Programme, in which students in Russian-medium ECEC centres and basic schools are taught at least $50 \%$ in Estonian, has existed since 2000. Since 2013, the Innove Foundation has supported schools and teachers in implementing the immersion programme and co-ordinates a network of regional methodological centres that support the teaching of Estonian through immersion. In the 2019/20 academic year, 3470 ECEC students, and 7369 basic school students participated in the immersion programme. The government aims to move all ECEC centres towards bilingual teaching by 2025 . The transition towards bilingual teaching is supported by the Professional Estonian-speaking Teacher to Every Russian-speaking Preschool Group programme (2018). This programme supported the placement of Estonian-language teachers in 53 Russian-medium pre-school groups in the 2018/19 academic year. An additional 30 pre-school groups benefitted from the programme in the 2019/20 academic year.

Over the past last ten years, Estonia has made progress in integrating students with special educational needs into mainstream schools. In 2017, amendments were made to the Preschool Child Care Institutions Act (Koolieelse lasteasutuse seadus) and the Basic and Upper Secondary Schools Act (Põhikooli- ja gümnaasiumiseadus) with the aim of promoting inclusion. One of the key aims of the amendments was to provide responsive and tailored support to students whose needs develop during their schooling. Schools are responsible for assessing the needs of the student, but can enlist enhanced support from external specialists. In 2018, a further amendment significantly increased the level of financial support available to municipalities to cover the costs of specialised provision. In the year 2020, a total of 19.9 million EUR was made available to municipalities for operating expenses. For 2020, Estonia set the target of $35 \%$ of students with severe special education needs enrolled in mainstream schools. This figure had reached $36.6 \%$ by the $2019 / 2020$ academic year.

A network of Pathfinder (Rajaleidja, 2015) centres, coordinated by the Innove Foundation, provide educational counselling services to parents, teachers, and other adults working with young people between the ages of 1.5 and 18 . Pathfinder centres identify the young people's learning and behavioural needs, and direct them towards additional support from specialists such as psychologists or speech therapists. During recent school closures, the Pathfinder centres continued to provide remote counselling and support to schools and families (see Spotlight 1).

\section{Figure 3. Selected equity and quality indicators for Estonia, PISA 2018}

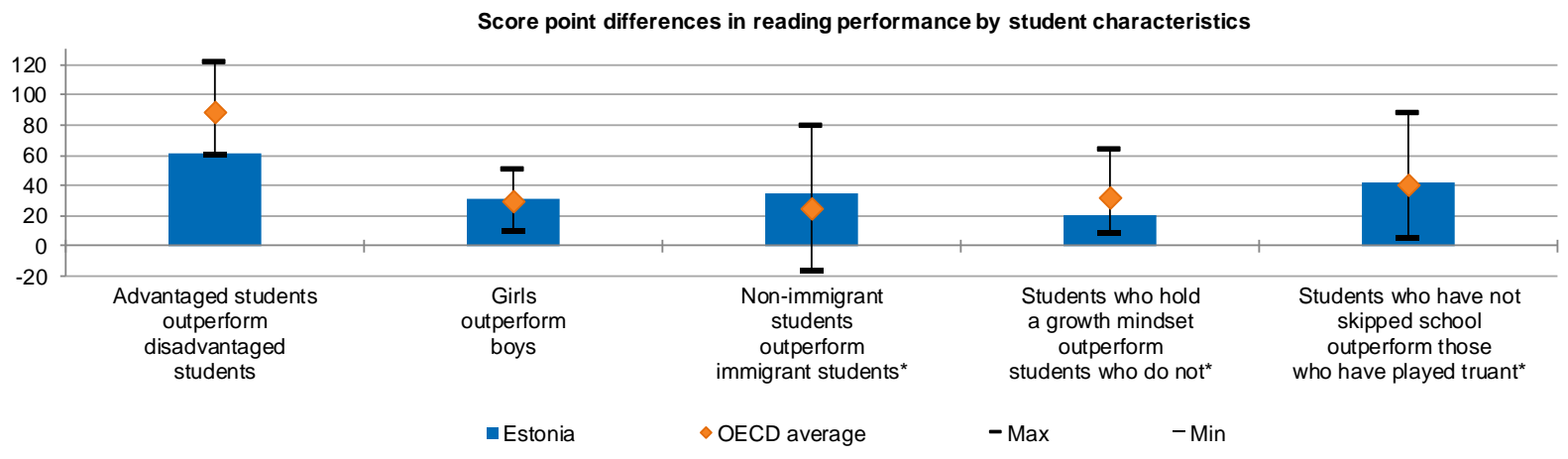

Percentage of low performers in reading

Percentage of high performers in reading
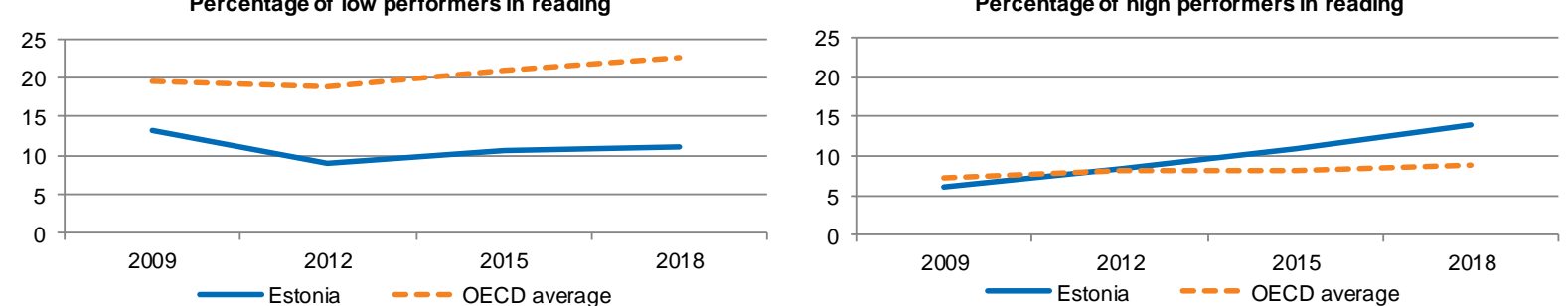

Note: Min"/"Max" refer to OECD countries with the lowest/highest values; [ $\left.{ }^{\star}\right]$ Score point difference after accounting for students' socio-economic status and language spoken at home

Source: OECD (2019), PISA 2018 Results (Volume I): What Students Know and Can Do, PISA, OECD Publishing, Paris, https://doi.org/10.1787/5f07c754en; OECD (2019), PISA 2018 Results (Volume II): Where All Students Can Succeed, PISA, OECD Publishing, Paris, https://doi.org/10.1787/b5fd1b8f-en; OECD (2020), PISA 2018 Results (Volume III): What School Life Means for Students' Lives, PISA, OECD Publishing, Paris, https://doi.org/10.1787/acd78851en. 


\section{PREPARING STUDENTS FOR THE FUTURE: NEED TO PROMOTE POSITIVE LABOUR MARKET OUTCOMES FOR ALL}

The capacity of a country to effectively develop informed skills and labour market perspectives can play an important role in the educational decisions of the population. In the OECD Survey of Adult Skills (PIAAC) 2012, adults in Estonia scored 276 points in literacy skills, above the OECD average of 268 points. Literacy scores were also higher than the OECD average across different age groups. Estonia's labour market conditions for the young have improved since the sharp declines in youth employment experienced in the global recession in 2008. At $11.2 \%$, Estonia's share of NEET (those aged 18-24 that are not employed or in further education or training), was also below the OECD average of $14.3 \%$ in 2018. However, regional disparities remain, including for NEET rates, being particularly high in north-eastern Estonia. Employment gaps between women and similarly educated men also exist.

Upper secondary education includes general education, which lasts three years, and vocational education, which can last up to four years. In 2018, 87.9\% of 25-34 year-olds in Estonia had attained at least upper secondary education (slightly above the OECD average of $85.4 \%$ ). Programmes on the VET track are available in both Russian and Estonian, whereas Estonian is the main language of instruction for general upper secondary and higher education. Students attending the general upper secondary track receive a leaving certificate and can either choose to attend university or to follow vocational courses. Since many lower secondary schools also offer upper secondary education on the general track, this often becomes the default choice for students wishing to remain in the same school. The OECD thus recommended separating the provision of basic and upper secondary education. Estonia has also aimed to reduce the number of basic schools providing upper secondary education (see Spotlight 2).

Indeed, vocational education and training can ease entry into the labour market. Recent VET reforms in Estonia have sought to improve transitions to the labour market by developing work-based learning and by clarifying the qualifications system, although making VET more attractive, particularly among higher-achieving students, remains a challenge. Estonia has set a target for $35 \%$ of basic school graduates to enter the vocational track by 2020 . However, this figure stood at $25-27 \%$ in the period 2013-18. A 2018 national survey showed limited awareness of students for VET programmes and the opportunities they offer. VET dropout rates have also continued to be a concern in Estonia, with onequarter of students failing to complete their studies. Estonia plans to include a performance-based element in its VET funding formula to offer incentives for timely completion (see "Funding").

In Estonia, higher education (HE) is divided into professional higher education (rakenduskõrgkool) and university (ülikoo). Both can lead to a doctorate and are accessible to graduates of general and vocational upper secondary education. Estonia's efforts to improve equality of access to HE include, for example, reforming and monitoring financial support arrangements for students and, in 2013, abolishing tuition fees for full-time students studying in Estonian (see "Funding"). In 2018, 43.6\% of 25-34 year-olds in Estonia had a tertiary-level qualification. This was close to the OECD average of $44.3 \%$ and represented an increase of 8 percentage points since 2008 . However, timely completion in $\mathrm{HE}$ is a challenge for Estonia, compared to other OECD countries with available data. In 2017, 59\% of those who entered a bachelor's programme had completed their programme within 3 years of the theoretical duration, compared to an average of $67 \%$. According to national forecasting data from 2018, the number of graduates from university and professional higher education was insufficient to meet future labour market demands. Improving completion rates in HE is therefore an urgent policy priority. To this end, the OECD has recommended reducing the difference between the cost of studying full-time and part-time, as the former may be more suitable for some students (students in Estonia tend more to work while studying than students in other European countries). Fee exemptions currently apply for part-time students in the fields of teaching and nursing.

Estonia is working to develop the supply of skills in the labour market. Estonia ranked in the bottom $40 \%$ of the OECD Skills Strategy Dashboard for the alignment of skills supply and labour market demand. Employers have found skills and labour shortages in some sectors, but also need to engage further in training their employees. At the same time, in 2019, $20.2 \%$ of 25-64 year-olds had participated in some kind of lifelong learning activity. This is a record high for Estonia, and is among the highest participation rates in the EU. In the wake of the COVID-19 crisis, Estonia also developed a platform for online adult learning opportunities (see Spotlight 1). Participation in adult learning can support learners in adapting to changed economic circumstances. With almost half of Estonian jobs at risk of automation or significant change, the development of up-to-date skills, including for a digital transformation, is key to providing Estonia's society with better future opportunities (see Spotlight 4).

\section{Key strengths and challenges (pre-crisis analysis)}

\section{Key strengths}

- Estonia has shown strong performance in adult literacy skills across different age groups.

- There has been an increased participation in adult learning in recent years.

\section{Key challenges}

- $\quad$ Making VET more attractive and improving completion at HE level.

- Making the education offer and delivery more relevant to the evolving labour market. 
12 | No. 13 - EDUCATION POLICY OUTLOOK IN ESTONIA

\section{Recent policies and practices}

The Vocational Educational Institution Act (Kutseõppeasutuse seadus) has been in place since 2013 to improve the quality of teaching and practical training, implement distributive leadership, and to modernise VET funding and infrastructure. Since 2015, the VET curriculum has been based on occupational standards. These are drawn up and regularly revised by professional councils. The standards describe the professional activities involved in different occupations and set out the knowledge, skills and attitudes necessary to be successful in the role. They inform curriculum design, assessment, recruitment, and professional training.

As part of the Labour Market and Education Cooperation Programme (2015), Estonia has sought to develop work-based learning practices in VET. The government has developed further guidelines for the implementation of work-based learning and provided training for supervisors and additional transportation and accommodation support for students. According to the guidelines, VET programmes at EQF levels 2-5 must now involve at least $50 \%$ work-based learning. However, the definition of work-based learning currently includes school-based workshops as well as learning experiences in the workplace. A recent OECD review (2019) recommended setting minimum expectations for learning in the workplace, which is essential for developing the soft skills required for professional life.

Estonia has also introduced a number of measures to improve labour market outcomes for higher education graduates. The government set an overall target of an $88 \%$ employment rate for graduates by 2020 . This target was achieved in 2018 , although the result for 2019 , at $87.5 \%$, was slightly below target. A national graduate survey captures information on the labour market participation of recent graduates. The higher education funding formula and quality assurance arrangements in Estonia now also take into account the employment rates of graduates. In addition, Estonia has extended its apprenticeships programme to tertiary education. After a successful pilot in 2017/18, apprenticeships were offered at Tallinn Healthcare College, Tallinn University of Technology, and Mainor Business school in the 2018/19 academic year.

Amendments to the Professions Act in 2015 established OSKA, a new labour market-monitoring and skills-forecasting system, which is used to inform career guidance, VET and tertiary education provision, and the provision of short reskilling courses in VET and HE. It draws on quantitative labour market and survey data and qualitative interviews with sectoral experts, who also provide feedback on existing qualifications. According to OECD evidence, Estonia has experienced challenges balancing the need to respond to the labour market trends identified through OSKA with the need to respond to student preferences in VET.

The Adult Education Act (2015) provides a framework for the provision of adult learning and establishes the legal entitlement of all citizens to lifelong learning opportunities. It also sets out obligations for employers to grant study leave to employees engaged in adult learning. At the same time, the act sets out procedures for ensuring the quality of adult learning, and places obligations on adult education providers and state and local governments).

Figure 4. Percentage of 18-24 year-olds in education and not in education, by work status, 2018

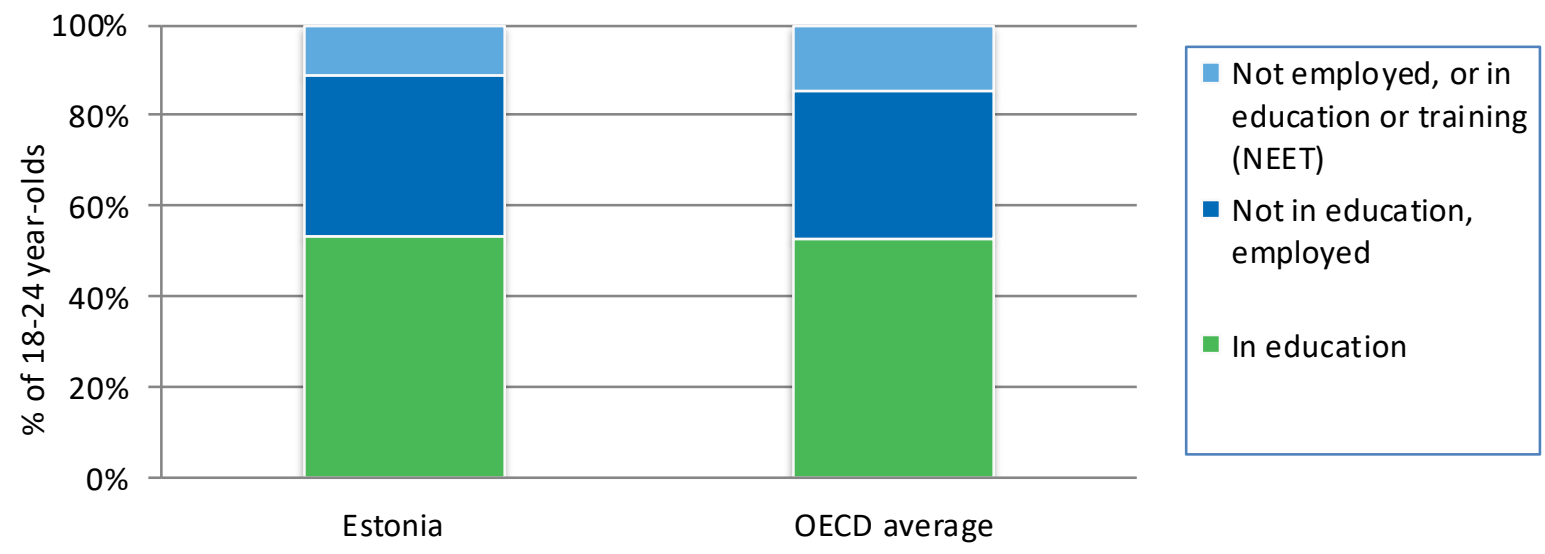

Source: OECD (2019), Education at a Glance 2019: OECD Indicators, OECD Publishing, Paris, https://doi.org/10.1787/f8d7880d-en. 


\section{Spotlight 4. Aligning Estonia's education system with the future: \\ Lifelong Learning Strategy 2020 (EÕS, 2014 - 2020)}

Estonia has outlined its vision for strategic improvement at all levels of the education system in the Estonian Lifelong Learning Strategy 2020 (Elukestva Õppe Strateegia, EÕS), which covers the period 2014-2020, and its successor, the Smart and Active Estonia 2035, which is currently under development.

The Lifelong Learning Strategy outlined five strategic goals for the entire education system, and set out measurable targets to track progress in each area:

- Change in the approach to learning: Implementation of an approach to learning that supports each learner's individual and social development, the acquisition of learning skills, creativity and entrepreneurship at all levels and in all types of education.

- Developing competent and motivated teachers and school leadership: Including efforts to increase teachers' salaries and to make the profession more competitive. There were also measures to improve teacher and school leaders' professional development.

- Alignment of lifelong learning opportunities with the needs of the labour market: Including efforts to improve the use of labour market data to inform educational provision, improving the quality of career guidance, and promoting work-based learning in VET and higher education.

- Placing a digital focus on lifelong learning: Improving the digital skills of the population, for example, by upgrading the digital infrastructure of schools and higher education institutions and incorporating a digital culture into the learning process.

- Ensuring equal opportunities and increased participation in lifelong learning: For example, through measures to increase access to ECEC and initiatives to improve the labour market participation of groups with lower competitiveness.

The implementation process of the EÕS entailed cross-level collaboration, including a steering committee comprised of 15 experts from different backgrounds. An implementation plan made by the Ministry of Education and Research was renewed every year in line with the state budget strategy. Goals and targets were benchmarked, measured and reviewed to assess the progress made on each indicator. For example: the participation rate in lifelong learning among adults was $12.9 \%$ in 2012 and was expected to reach $20 \%$ by 2020 . This figure stood at $20.2 \%$ in 2019. Other targets included lowering the NEET rate from $10.5 \%$ (in 2012) to below $9 \%$ by 2020 , and increasing employment rates for recent graduates (from $73.9 \%$ to at least $82 \%$ ). According to national data, the NEET rate stood at $9.8 \%$ in 2018 and the employment rate for recent graduates had reached $77 \%$ by 2017.

A mid-term evaluation of the Lifelong Learning Strategy, carried out by the Praxis think tank and the Estonia Centre for Applied Research (Centar), was published in 2019. The evaluation found significant progress in making digital learning resources more widely available, and in assessing the digital competencies of students and teachers, but identified a need to improve teachers' digital skills. A significant increase in participation in adult learning was also identified, which appeared to function relatively well. A key recommendation was that strategic and operational planning needed to be better integrated in the next phase of the strategy.

Strategic planning for Smart and Active Estonia 2035 has also involved input from a range of different stakeholders. Three expert working groups set out the overall vision and goals for the strategy. The Ministry of Education and Research established further working groups to develop more detailed development plans. These working groups included partners from local government, young people, parents, researchers, and entrepreneurs. The development plans were due to be finalised during the year 2020 for implementation in 2021-24. Alongside this process, the Ministry has organised a series of face-to-face and virtual public consultation exercises. Estonia expects these to continue into 2021. Key goals of the strategy include providing more flexible pathways for learners, promoting Estonian language and culture, a focus on skills development and collaborative processes in learning, and improving the quality of higher education and research. 


\section{SCHOOL IMPROVEMENT: SUSTAINED EFFORTS TO RAISE THE STATUS OF TEACHERS AND SCHOOL LEADERS}

Developing positive learning environments for students which enable school leaders and teachers to succeed is essential in raising achievement in schools. The disciplinary climate in Estonian schools, as reported by students, has shown improvements across PISA cycles. In PISA 2018, it was among the most favourable in the OECD, with a disciplinary climate index of 0.20 (the OECD average index value was 0.04). Similarly, in TALIS 2018, teachers in Estonia reported that $86 \%$ of classroom time was spent on actual teaching and learning, compared to an OECD average of $78 \%$. Some $97 \%$ of teachers also agreed that students and teachers usually get on well with each other. Similarly, in PISA 2018 , only $17.5 \%$ of 15 -year-olds reported skipping at least one day of school in the two weeks prior to the PISA test, compared to the OECD average of $21.3 \%$.

Attracting, retaining and developing good-quality school leaders is key to improving the quality of learning environments and promoting effective school leadership. School leaders in Estonia have extensive responsibilities compared to their peers in other OECD countries (see "Governance"). However, despite having this important role, in TALIS 2018, only one-third of school principals reported having received principals' training or training in school administration before taking up their post (30.1\%, matching the OECD average of $30.7 \%)$. This highlights the importance of providing them with stronger professional learning opportunities while in the post to support their function. The role of the school leader also has one of the lowest wage premiums in the OECD. In 2018, school leaders in Estonia earned $24 \%$ more than teachers, well below the OECD of average $50 \%$. Estonia has introduced a range of measures to improve school leaders' initial preparation and continuing professional development.

A strong supply of highly qualified and engaged teachers is vital in every education system too. New teachers in Estonia are required to complete a specialised programme at bachelor's (for ECEC and VET teachers) or master's level (for subject and class teachers). Although the number of teachers in Estonia exceeds the number of teaching posts, there are teacher shortages in rural schools and in subjects such as mathematics and science. Estonia also has an ageing teaching workforce and will need to attract new entrants to the profession. In TALIS 2018 , the proportion of lower secondary teachers aged 50 or more, at $53.2 \%$, was among the highest in the OECD, where the average was 35.4\%. Digital learning has been a focus for teachers' professional development in recent years. In TALIS 2018, the share of teachers who reported that information and communications technology (ICT) skills for teaching were included in their professional development activities, at $74.1 \%$, was among the highest in the OECD (the OECD average was $60.4 \%$ ). Estonia has also been committed to including more SEN students in mainstream schools. Building teachers' capacity to meet the needs of these students will be an important priority going forward (see "Equity and Quality"). In TALIS 2018, 47\% of school principals reported that the quality of instruction was hindered by a shortage in teacher competence in teaching students with special needs; this was higher than the OECD average of $32.1 \%$. Training in teaching students with special needs scores highest among teachers' reported professional development needs. The professional standards for teachers, which form the basis of initial teacher education and continuing professional development, have recently been updated with an increased focus on digital pedagogy and inclusive education (see "Recent policies and practices"). The development of digital skills supported the transition to online learning during the COVID-19 crisis (see Spotlight 1).

Estonia has improved teaching conditions, with comparatively lower teaching hours, average salaries and average teacher-to-student ratios. Teachers teach annually for 585 hours at primary level, and 602 hours at lower secondary level (the OECD averages are 783 and 709 hours, respectively). In 2017, teacher-to-student ratios were 13 for primary and secondary school (the respective OECD averages were 15 and 13). There have been efforts to increase teachers' salaries and to raise the status of the profession (see "Recent policies and practices"). In 2017, teachers earned $91 \%$ of the average salary of a full-time full-year worker with tertiary education, matching the OECD average. Also, the share of teachers that felt the teaching profession was valued in society increased from $13.7 \%$ to $26.4 \%$ between 2013 and 2018 (with an OECD average of $25.8 \%$, and a national target of $20 \%$ by 2020 ).

\section{Key strengths and challenges in school improvement (pre-crisis analysis)}

\section{Key strengths}

- Estonia has made efforts to improve teachers' salaries and strengthen the status of the profession.

- Students and teachers in Estonia have reported positive learning environments.

\section{Key challenges}

- Further supporting strong school leadership.

- Balancing teachers' oversupply and shortage, particularly with an ageing profession.

- Building teacher capacity to meet the needs of SEN students and enhance their digital skills. 


\section{Recent policies and practices}

Improving teachers' salaries was one of the goals of the Estonian Lifelong Learning Strategy 2014-2020 (see Spotlight 2). As a result of these efforts, the average teacher salary increased by $59 \%$ between 2013 and 2018 , which outstripped the national average salary increase. In 2019, the minimum teacher monthly salary was set at EUR 1250 , bringing the average salary to EUR 1500 . The government also provided additional funding to municipalities in order to increase the salaries of ECEC teachers, which have typically been lower than other teachers' salaries. According to national-level data, the average teacher earned $113 \%$ of the average national salary in 2018. Estonia set a target for teachers' salaries to match the average salaries of higher education graduates by 2020 (roughly $120 \%$ of the average national salary).

Another goal has been to increase the share of teachers who are under the age of 30 to $12.5 \%$ by 2020 . Estonia currently has one of the fastest ageing teaching workforces in the EU and across OECD countries. New entrants to the profession now receive early career support subsidies. In 2019, the amount was set at EUR 12783 to be paid in three instalments over three years. Recipients of the subsidy agree to stay in the system for five years. A recent report from Estonia paints a mixed picture with regards to improving the attractiveness of teaching. On the one hand, in 2018/19, applications to initial teacher education programmes at the universities of Tallinn and Tartu increased by $24 \%$ compared to the previous year. However, the number of applications per place was 0.9 . More recent national data for the 2020/21 academic year for the University of Tartu show that this was 0.85 .

Furthermore, Estonia introduced a new competence-based career structure and teacher certification process in 2014. The structure has four career grades - ranging from teacher to master teacher - with each grade based on qualifications, professional competence, and experience. The certification process consists of a portfolio assessment and a 30-minute interview with an external panel. A 2016 OECD report had found that the new structure had many advantages over the previous teacher accreditation system, which was complex and resource-intensive. Firstly, the new process became more focused on teaching practice. Since the Estonian Association of Teachers is the awarding body for the qualification, the teaching profession also gained ownership of the process. However, the report recommended making the process mandatory and formally linking it to salary levels. New professional standards for the different grades came into effect in 2020. These reflect an increased focus on inclusive education and digital pedagogy. The overall certification process remains voluntary and does not influence progression on the salary scale.

\section{Figure 5. The learning environment according to students, PISA 2018}

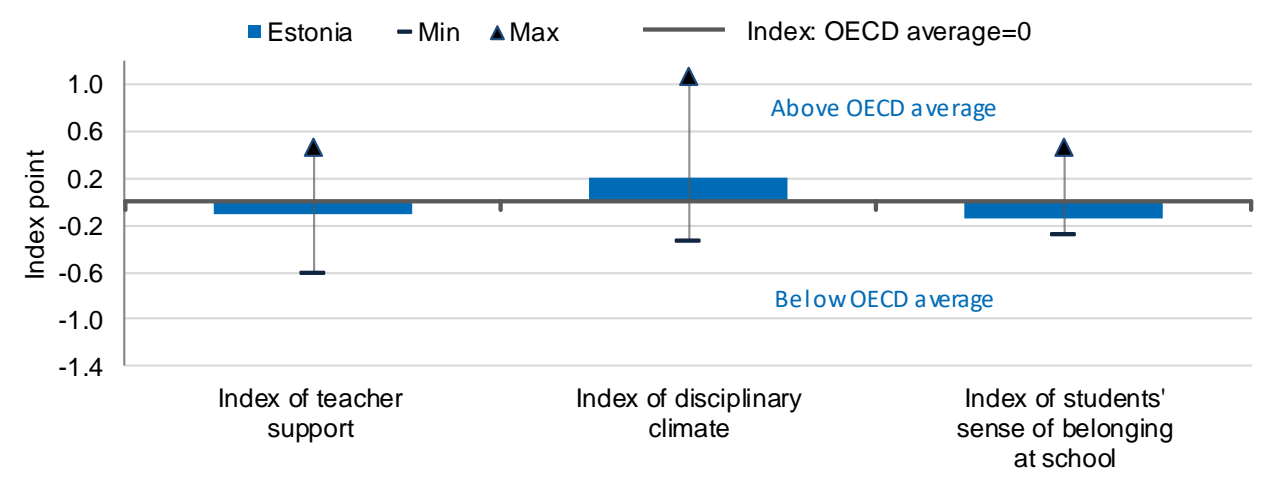

Note: "Min"/“Max" refer to OECD countries with the lowest/highest values.

Source: OECD (2020), PISA 2018 Results (Volume III): What School Life Means for Students' Lives, PISA, OECD Publishing, Paris, https://doi.org/10.1787/acd78851-en. 


\section{EVALUATION AND ASSESSMENT: STRENGTHENING A CULTURE OF EVALUATION AND FEEDBACK}

Defining strategies for evaluation and assessment is an important step towards improving student outcomes and developing a better and more equitable school system. Furthermore, transparent evaluation mechanisms can help systems to better respond to changing needs in contexts of disruption. System evaluations in Estonia aim to provide evidence on the overall performance of the education system. The Estonian Ministry of Education and Research publishes an annual review, which brings together data from internal and external evaluations, and covers pre-primary to tertiary education. Estonia also participates in large-scale international studies, such as PISA.

In Estonia, external school evaluation of the learning outcomes set out in the national curriculum takes place through final examinations in basic and upper secondary schools. The Ministry of Education and Research also carries out thematic reviews and individual inspections of pre-primary and school education. A new concept for external evaluation (2014), seeks to improve the quality of information about the education system available to the public, as well as the quality of feedback given to schools about their performance. Schools and pre-schools are also required to implement internal evaluations, and can enlist the support of trained counsellors for this.

According to OECD evidence, a teacher appraisal model with the following two components can strengthen teachers as professionals: an improvement component (emphasising developmental evaluation) and a career progression component (a model of certification of competencies for practice within and across career paths, associated with career advancement and based on a greater variety of instruments). Estonia has put in place internal teacher appraisals and non-mandatory teacher certification processes that give access to the higher levels of the career structure. Teacher appraisal levels as reported in TALIS 2018 were higher than average; $80.1 \%$ of lower secondary teachers had principals who reported formally appraising their teachers at least once a year, compared to the OECD average of $63.5 \%$. In addition, $63.9 \%$ of principals reported that formative discussions follow appraisal either most or all of the time, which was similar to the OECD average of 63.3\%. However, only $39.9 \%$ of principals reported that a development or training plan is mostly or always put in place after appraisal (OECD average: $46.2 \%)$. In 2016, the OECD recommended aligning teacher appraisal with the teacher certification process and making teacher certification mandatory. The same report highlighted a need to develop an appraisal process for school leaders; this has been identified as a priority in the Smart and Active Estonia 2035 strategy.

Schools in Estonia appear to make use of both formative and summative student assessment practices. Teachers are required to give students regular oral and written feedback based on expected learning outcomes, and schools provide written summative feedback at least twice per year. Standardised tests and project-based assessments at the end of basic school aim to provide comparable feedback to students, parents, schools and the state, and to inform student progression. To graduate from upper secondary school, students must complete a research paper and sit national exams in Estonian language, mathematics, and a foreign language. Evidence from TALIS suggests some progress in embedding formative assessment practices, although with room for improvement. In TALIS 2018, some $77 \%$ of teachers reported "frequently" or "always" administering their own assessments; a 21.6 percentage point increase between 2013 and 2018 (OECD average: 77\%). However, teachers in Estonia were less likely to provide written feedback on student work in addition to a grade (42.1\%), and less likely to let students evaluate their own progress (27.8\%) compared to the respective OECD averages of $57.5 \%$ and $41 \%$. In the context of the COVID-19 pandemic, Estonia prioritised verbal feedback in the early stages of recent school closures, and recommended that schools conduct an online development interview with students and parents (see Spotlight 1).

At higher education level, the Estonian Quality Assurance Agency for Higher and Vocational Education (EKKA) conducts external evaluations in the VET and tertiary sectors. It is responsible for the accreditation of study programmes and carried out an accreditation of all Estonian higher education institutions between 2012 and 2018 (see "Governance"). The agency also provides counselling and training to educational institutions and makes recommendations based on its analysis of internal evaluations. Changes introduced in 2019/20 replaced the overall assessment of curriculum groups in higher education by a thematic assessment in order to reduce the administrative burden of the process. Quality assurance processes for VET were also revised in 2019. The new procedure, to take place once every six years, emphasises formative assessment and feedback to VET institutions, and is no longer directly linked to an institutions' right to provide VET education. In 2019, an OECD report recommended strengthening quality assurance arrangements for VET by including a minimum requirement for learning in the workplace. EKKA is also piloting a quality assessment model for adult education.

\section{Key strengths and challenges in evaluation and assessment (pre-crisis analysis)}

\section{Key strengths}

- Extensive educational database that brings together evaluations at national and school level.

- Various forms of feedback available to teachers to improve learning.

\section{Key challenges}

- Aligning teacher appraisal with the new career structure and certification process, and developing appraisals for school leaders.

- Facilitating quality assurance processes in $\mathrm{HE}$ and strengthening them in VET. 


\section{7 | No. 13 - EDUCATION POLICY OUTLOOK IN ESTONIA}

\section{Recent policies and practices}

.One of the indicators of the Estonian Lifelong Learning Strategy relates to stakeholder satisfaction with the education system. With this in mind, the Estonian Ministry of Education and Research has worked with the Centre of Applied Social Sciences at the University of Tartu to conduct a range of satisfaction surveys. These were piloted in 2016, and fully implemented in 2018. The surveys cover all levels of the education system, from pre-primary through to tertiary and adult education. Students in general schools are surveyed every year, and surveys for other education levels, and for parents and teachers, take place every three years. Survey questions relate to stakeholder satisfaction with the school environment and specific aspects of student well-being and performance. Following the pilot study, the concept of satisfaction was further developed and the questionnaires were adjusted to make them more age-appropriate. The 2018 survey of general school students also gathered stakeholder views on VET. Participating schools and school owners receive a report summarising the results from their school across different groups of stakeholders, and comparing this to the national average. In 2018, as well as general school students, some 19000 parents of students in basic school and 7500 teachers participated in the survey. The next parent and teacher surveys are due to take place in 2021. In 2019, Foundation Innove surveyed 12407 fourth-grade students, 9920 eighth-grade students, 5616 eleventh-grade students and 1046 adult high-school students. The next round of surveys was planned for early 2020 and was due to include students in VET as well as SEN students. In the context of the pandemic, Estonia has collected feedback from teachers, schools leaders and parents on the government's response to the COVID-19 epidemic (see Spotlight 1). This feedback will be important as Estonia seeks to strengthen the education system for future resilience.

As part of efforts to improve the digital competences of the population, Estonia has developed tools to assess the digital skills of students and to evaluate the digital infrastructure of schools. The Foundation Innove worked with researchers from the universities of Tallinn and Tartu to develop digital competency assessments (2019) for students in grades 9 and 12, and those in upper secondary VET. Students receive verbal feedback on their performance, and schools receive feedback on digital competencies at the school level. At the school level, the Digital Mirror (2018) is a tool used to help schools to assess their digital maturity and develop an improvement plan. Some 449 general education schools were due to complete the self-evaluation process in 2019. The mid-term evaluation of the Lifelong Learning Strategy highlights the measurement of students and teachers' digital competences, and of schools' digital readiness, as areas of success. Further developing the digital readiness of students, teachers and schools will remain important going forward, as Estonia strengthens systemic resilience in the medium to longer term (see Spotlight 1).

Figure 6. Percentage of students in schools where the principal reported assessments of students in national modal grade for 15-year-olds, PISA 2015

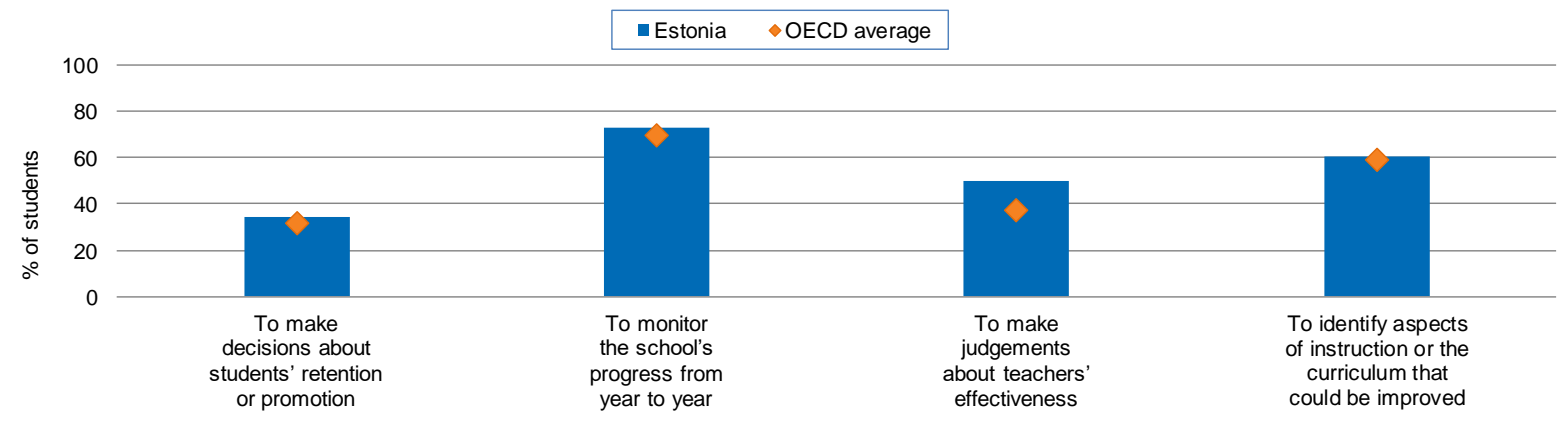

Source: OECD (2016), PISA 2015 Results (Volume II): Policies and Practices for Successful Schools, PISA, OECD Publishing, Paris, http://dx.doi.org/10.1787/9789264267510-en. 


\section{GOVERNANCE: A HIGHLY DECENTRALISED SYSTEM EVOLVING IN A CONTEXT OF DEMOGRAPHIC CHANGE}

The Estonian government and the Ministry of Education and Research are responsible for education policy and overall strategy. The Ministry of Education and Research also has responsibilities in the areas of curriculum and funding. The Estonian Lifelong Learning Strategy (2012-2020) has provided the guiding principles for education policy development throughout the system (see Spotlight 2). Municipalities have an obligation to ensure pre-primary and compulsory education provision for every child within their jurisdiction. They also have responsibility for monitoring attendance, hiring school leaders, establishing school supervisory bodies, and implementing county plans for educational development. Other bodies also shape education policy:

- The Innove Foundation develops and implements a range of external assessments - such as national tests at the end of basic and upper secondary school - and disseminates data from these assessments. It also co-ordinates development activities and implements projects funded through EU structural support.

- Education departments within county governments supervise pre-primary and general education and often facilitate co-ordination between municipalities, and between national and local government.

- The Estonian Quality Agency for Higher and Vocational Education (EKKA) is responsible for quality assurance in VET and higher education.

- The Archimedes Foundation co-ordinates and implements different international and national projects in the field of training, education and research, mainly related to youth and higher education.

- The Estonian Qualifications Authority develops and oversees the occupational qualifications system, which acts as an interface between the education system and the labour market. It is also responsible for the analysis of labour market and skills needs through the OSKA programme.

Other stakeholders involved in the policy consultation processes led by the Ministry of Education and Research include the Association of Municipalities of Estonia, professional bodies such as the Estonian Association of Heads of Schools and the Estonian Education Personnel Union, and student and parent organisations. Key stakeholders in higher education include Universities Estonia and the Estonian Rectors' Conference of Universities of Applied Sciences.

The administration of Estonian ECEC centres and schools is highly decentralised. Municipalities own and run the majority of ECEC centres and general schools in Estonia, often delegating a large number of administrative and instructional responsibilities to them. While vocational schools are mostly owned by the state, they also have extensive autonomy. In 2017, the share of key decisions taken by Estonian schools, at 58.3\%, was among the highest in the OECD, where the average was $33.95 \%$. This gives school leaders a high degree of autonomy. In addition to leading teaching and learning, Estonian school leaders establish teachers' salaries, manage financial resources, and are responsible for quality assurance. Indeed, in TALIS 2018, the share of school principals who reported having a significant responsibility for deciding on budget allocations with in the school, or establishing teachers' starting salaries, was among the highest in the OECD. However, Estonian school principals also reported to a lower extent collaborating with their peers from other schools on challenging work tasks, compared to their peers at the OECD. This points to a need to develop school principals' wider collaborative engagement to support them in coping with shared challenges, and exploring further possibilities for improvement. Estonia's School Network Programme aims to improve quality and efficiency in education by consolidating its network of schools in the context of demographic change (see Spotlight 4). However, the pace of change has been slow and uneven across municipalities. Some municipalities will require continued state support to achieve further consolidation.

Higher education institutions in Estonia also have a high level of autonomy within the limits set out by the Higher Education Act. The Estonian Parliament (Riigikogu) establishes general funding principles for higher education, while the government sets standards for higher education. A new management structure for universities was introduced in 2019 as part of changes to the Higher Education Code. Within the new structure, the council operates as the highest decision-making body, and the senate is responsible for academic decision-making (see "Recent policies and practices"). In professional higher education institutions, the council is responsible for strategic development and financial affairs. An advisory body, including representatives from the wider community, ensures a connection between the institution and society.

\section{Key strengths and challenges on governance (pre-crisis analysis)}

\section{Key strengths}

- Municipalities and school leaders have a high degree of autonomy.

- Recent measures aim at improving the governance of higher education.

\section{Key challenges}

- Strengthening collaboration between school principals.

- Supporting municipalities in consolidating their school networks in a context of demographic change. 


\section{Recent policies and practices}

Governance reforms took place in the two largest higher education institutions in Estonia (University of Tartu [UT] and Tallinn University of Technology [TTÜ]) in 2011 and 2015, respectively, to increase the voice of students and external representatives in the universities' decision-making processes. These measures formed the basis for the management structure that was introduced for all universities in 2019. A council, which is the highest decision-making body, is made up of university leadership and external representatives, and is responsible for long-term development and ensuring the achievement of the university's objectives. The Senate is the academic decision-making body and includes student representatives. It is responsible for ensuring quality in the university and for decisions relating to teaching, research, and development. These arrangements are set out in a specific government act for each university.

The reform of the national curriculum for basic and upper secondary schools (2014) aimed to put students at the centre of learning. The curriculum for basic and upper secondary school is now based on eight competencies that should be developed throughout a young person's education. The reforms aim to give schools and teachers freedom to organise the learning process in a way that best fits the school context and student needs. Subject-specific curricula provide opportunities for inter-disciplinary learning. Formative assessment is a key pillar of the shift from teaching towards learning. Estonia drew up an action plan for the development of new syllabi in 2016 and for an update of the core curriculum in 2018. This includes draft syllabi for ICT and entrepreneurship at lower and upper secondary level. These proposals are currently being piloted to assess their suitability as the basis for a new curriculum, and to identify needs for new subject areas and teacher training. Estonia aims for the revised curriculum to support the inclusion of students with SEN in mainstream education, taking account of the specific needs of different learners and allowing for differentiated learning outcomes.

The responsibilities of the Estonian Quality Agency for Higher and Vocational Education (EKKA, previously named Estonia Higher Education Quality Agency), the agency responsible for quality assurance in higher education, have changed over the last decade. In 2008, EKKA mandated that an assessment and accreditation of the quality of study programmes in higher education institutions should be conducted every seven years. Accreditation must also provide feedback about the management and work of the higher education institution (HEI) as a whole. Between 2012 and 2018, all HEls underwent the accreditation process, and two institutions failed to be accredited (in 2019, at least one of them had to be closed down). EKKA is reviewed externally every five years by the European Association for Quality Assurance in Higher Education (ENQA). It was renewed until 2023 following a review in 2017. In 2018, the ENQA found EKKA to be an open and transparent organisation in which stakeholders had a high level of trust. The report made a number of recommendations to enhance information exchange with stakeholders and to incorporate student voice in the evaluation processes. EKKA is currently working on strengthening the role of experts in the feedback process between HEls and EKKA.

\section{Figure 7 Percentage of decisions taken at each level of government for public lower secondary schools (2017)}

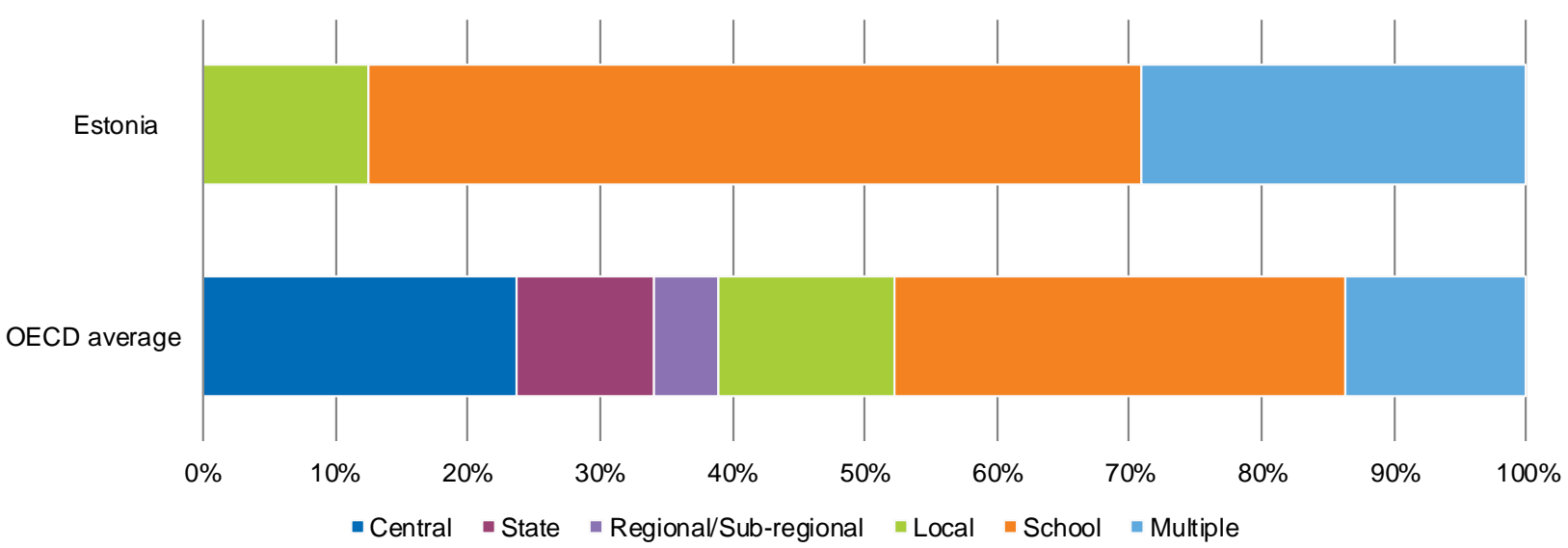

Note: This figure considers four domains of decision-making: 1) Organisation of instruction; 2) Personnel management; 3) Planning and structures, and; 4) Resources.

Source: OECD (2018), Education at a Glance 2018: OECD Indicators, OECD Publishing, Paris, https://doi.org/10.1787/eag-2018-en. 


\section{0 | No. 13 - EDUCATION POLICY OUTLOOK IN ESTONIA}

\section{Spotlight 5. School consolidation as a priority in Estonia}

Estonia has an extensive and comprehensive network of schools that aims to ensure full access for all students. However, between $2005 / 06$ and $2013 / 14$, the size of the student population contracted by about $22 \%$. This led to a growing number of schools with small classes and under-utilised facilities, particularly in rural areas. In order to improve quality and efficiency, the Estonian Ministry of Education and Research implemented the Reorganisation of school networks policy (koolivõrgu korrastamine) $(2004 / 05,2012)$ and the School network program (20142020).

The key elements to the current strategy are:

- Separating basic and upper secondary education and reducing the overall number of upper secondary schools. The aim is to reduce this figure to under 100 by 2023.

- $\quad$ Creating a network of state-run upper secondary schools. Each county capital is to have a state upper secondary school by 2020.

- Creating incentives for municipalities to consolidate their school networks. Those that reduce the number of schools are eligible for special investment grants.

- $\quad$ Reducing the number of SEN schools by $1 / 3$ and increasing the percentage of SEN in mainstream schools from $28 \%$ to $35 \%$ between 2014 and 2020.

The decision to close a school lies with the school owner (the municipality or the state). The decision-making process takes account of factors such as the quality and cost of education currently provided, the potential commutes of all affected students, and student preferences for studying in larger or smaller cities. To be eligible for support grants, municipalities must demonstrate that the proposed consolidation will lead to a reduction in expenditure. They must also contribute $15 \%$ of the cost. Financial support from the national government can be used to adapt or repurpose existing infrastructure, or to support redundant teachers. Municipalities also receive grants to adapt their facilities to support the inclusion of SEN students.

As a result of these efforts, 78 general education schools were closed between 2005 and 2013 (with primary schools representing the majority). Other schools revised their offerings, for example, from full-cycle school to basic school, from basic school to primary school. As many as 31 schools merged during the same period. The first state upper secondary school opened in 2012. As of 2018, 15 of the 24 planned upper secondary schools had opened. The total number of upper secondary schools reduced from 200 in 2013 to 160 in 2018 . Much of the building and renovation work has been completed.

A recent evaluation of the Estonian Lifelong Learning Strategy found that the consolidation of the school network needed to be significantly accelerated if government targets were to be met. This conclusion is supported by data from the European Commission, which suggests that in 2018, one-third of general schools still had fewer than 100 students. At the time of the evaluation, only $20 \%$ of the budget for the program had been allocated. The evaluation report highlighted the importance of collaboration between the central state and local government in achieving the aims of the school network program. In particular, it suggested that the central state would need to continue to support some municipalities in taking some of the difficult decisions that the consolidation of the school network entails. It also recommended that discussions on the content and purpose of education should be held with different stakeholders before any further school network decisions are made. 


\section{FUNDING: ENSURING RESOURCES SUSTAINABILITY FOR THE EDUCATION SYSTEM}

Estonia's education system has delivered above-average outcomes in PISA and the OECD Survey of Adult Skills (PIAAC) 2012 despite having below-average overall education expenditure. In 2016, overall expenditure from primary to tertiary education as a proportion of GDP, at $4.4 \%$, was below the OECD average of $5 \%$. Annual expenditure per student in USD was also below the OECD average at all education levels.

Some education levels have been given priority in spending. In 2016, Estonia had one of the highest levels of expenditure on ECEC as percentage of GDP in the OECD, with $1.2 \%$ (far above the OECD average of $0.8 \%$ ). Spending in higher education has also increased significantly, as Estonia has sought to reduce the cost of full-time study borne by households; expenditure per student increased by 68\% between 2010 and 2016 (OECD average increase: 8\%). At the school level, recent increases in teachers' salaries are expected to lead to increases in overall education spending. At the same time, the modernisation of the school network has largely been completed, meaning that spending on infrastructure is likely to decline. Since its accession to the EU in 2004, Estonia has received funding from the European Development Fund and the European Social Fund. This funding has been invested towards the modernisation of the VET network, improvements in higher education, and research and development activities. The current allocation of funding ends in 2020, after which point funding from international sources is likely to decrease. An OECD report (2019) highlights the challenge of finding new funding sources for activities currently supported by EU funding.

Public expenditure is the main source of funding of Estonia's education system. ECEC, primary and secondary institutions receive their funding from the municipalities. Both private and public ECEC institutions receive financial support from the municipalities. Municipalities have also received funding to create additional ECEC places, with some co-operating with private providers to meet local demand. However, the rates for public pre-primary education remain higher than for most other OECD countries. In the academic year 2019/20, municipal ECEC institutions represented $91 \%$ of the total number of childcare institutions. For primary and secondary education, municipalities receive a national government grant based on four earmarked components: study materials, school lunches, professional development, and teacher and school leader salaries. Teacher salary allocations are based on a per-student formula, adjusted to provide sufficient funding to smaller municipalities while encouraging further consolidation of the school network (see Spotlight 4). Municipalities decide on how to allocate funding to individual schools, and schools have a high level of autonomy over their budgets. They can also raise additional funds through donations, parental contributions, and rental of facilities. Most VET schools are owned by the national government and are funded through the state budget. Estonia has moved towards a performance-related funding formula for VET in 2020 (see "Recent policies and practices").

In 2016, the share of expenditure from primary to tertiary-level education coming from private sources, including international sources, was $11.3 \%$ (well below the OECD average of 17.4\%). At pre-primary level, municipalities set the level of parental contribution, which is capped at $20 \%$ of the national minimum wage. At the school level, most students in Estonia attend publically owned institutions, and these are free of charge. Recent reforms aimed at promoting school choice have led to an increase in the number of private schools in Estonia. These reforms give private schools access to the same funding as municipal schools. Private schools may also charge a tuition fee in accordance with government regulations. Private higher education institutions (HEI) may receive government funding if considered necessary, and this aligns with the state's strategic goals and labour market needs. If government funding is provided, however, then private HEls are not allowed to charge tuition fees to the students enrolled in the programme receiving the subsidy. For 2020, only one private university received this support.

Higher education institutions (HEI) in Estonia receive a block grant from the government. The funding formula includes a performance-related component since 2013, with revisions in 2017 to provide more stable revenues (see "Recent policies and practices"). HEI have relatively high autonomy to spend their block grant. Public universities can also set the fee level for programmes not covered by the tuition fees exemption (e.g. programmes in English and part-time programmes), and can obtain funding from commercial research and by selling infrastructure. According to an OECD report from 2019, though, higher education funding from private non-household sources is relatively low in Estonia, and tends to fluctuate year on year. In 2016, it stood at $6 \%$, compared to an OECD average of $9 \%$. Under the Higher Education Reform (2013), higher education became free of charge for students studying full-time in Estonian in a public higher education institution. The reform also introduced a needs-based support system, with a study allowance of EUR 75-220 per month for students from disadvantaged backgrounds.

\section{Key strengths and challenges of funding education system (pre-crisis analysis)}

\section{Key strengths}

- Estonia achieves good educational outcomes with comparatively low educational expenditure.

- Estonia has proportionately high levels of investment in ECEC.

\section{Key challenges}

- Ensuring continued funding for activities currently supported by EU funding.

- Increasing the level of private non-household funding in higher education 


\section{Recent policies and practices}

In 2017, Estonia's higher education funding model shifted from a largely performance-based system to an $80 \%$ baseline and $20 \%$ performance funding (of which up to $17 \%$ are based on performance indicators and up to $3 \%$ are based on performance agreements). According to an OECD report from 2019, the previous model - adopted under the Higher Education Reform (2013) - led to sudden fluctuations in the funding streams of some institutions. As well as providing greater financial stability for the higher education sector, the new funding formula has supported the objectives of the Estonian Lifelong Learning Strategy. Indicators include the proportion of students graduating within the nominal timeframe (weighted at $35 \%$ ), the proportion of graduates employed or in further study (20\%), the proportion of foreign students (10\%) and students studying abroad (10\%).

There has also been a shift towards awarding grants and scholarships on the basis of economic need rather than on the basis of academic merit. Data from 2018 indicate minor improvements in the share of students graduating on time, the share of students studying in priority fields, an increase in the proportion of foreign students in Estonian universities, and in the number of Estonian students studying abroad.

In 2018, Estonia also began work on a new funding model for VET institutions. The proposed new model includes a basic component, covering at least $80 \%$ of an institution's funding, and a performance-based component, which accounts for up to $20 \%$ of the funding. The model was partially implemented in 2020. The performance-related element, which remains to be implemented, will provide incentives for timely completion, as well as indicators for graduate employment rates and participation in further study. There are plans to introduce performance-related funding at a later stage, though these depend on budget allocations.

\section{Figure 8. Annual expenditure per student (2016) and recent trends, by level of education}

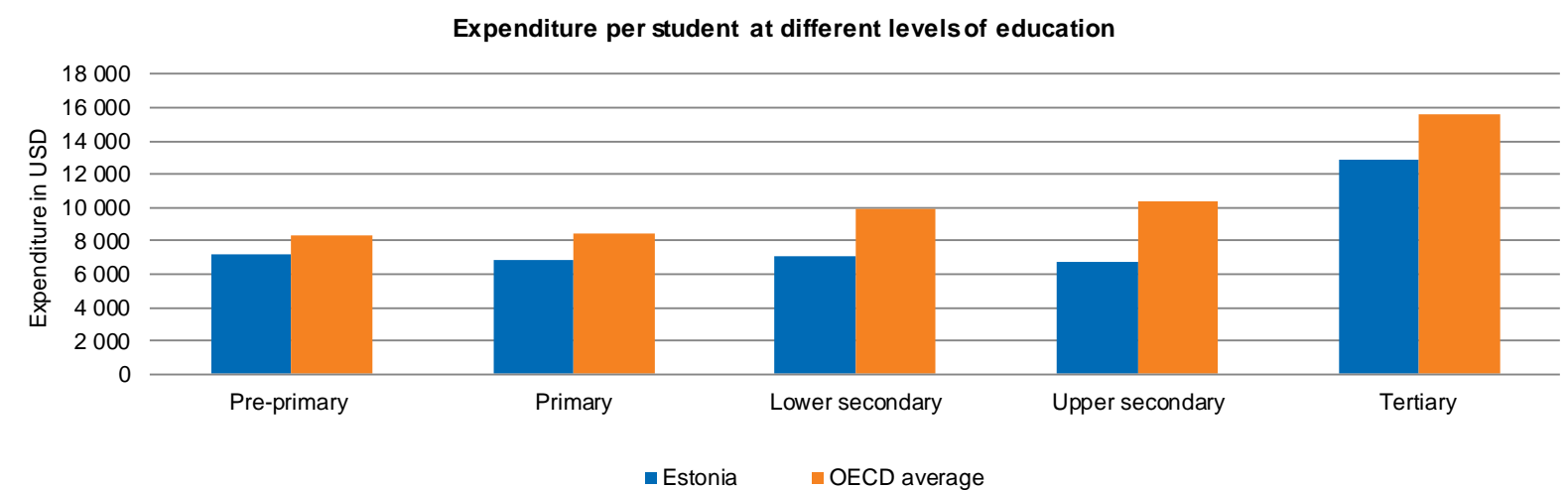

Change in expenditure per student, primary, secondary and post-secondary non-tertiary education $(2010=100)$

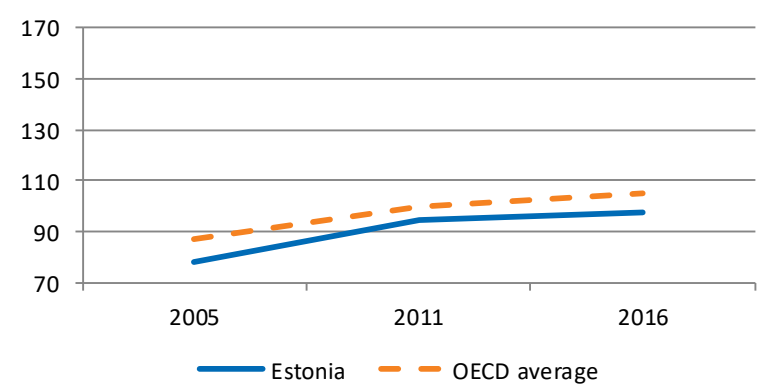

Change in expenditure per student, tertiary education $(2010=100)$

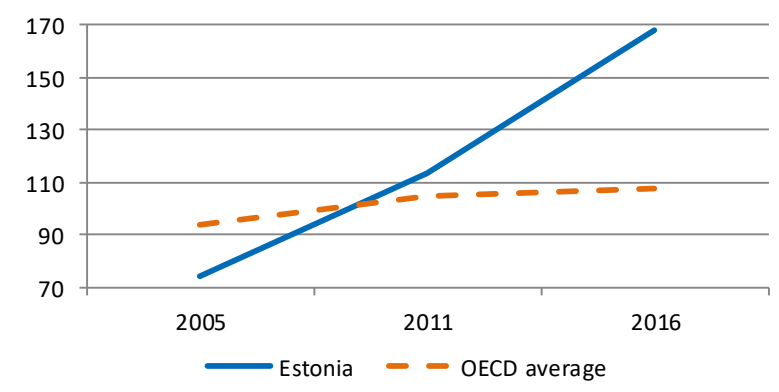

Source: OECD (2019), Education at a Glance 2019: OECD Indicators, OECD Publishing, Paris, https://doi.org/10.1787/f8d7880d-en. 


\section{ANNEX A: STRUCTURE OF ESTONIA'S EDUCATION SYSTEM}

Theoretical starting age

\section{Estonia}

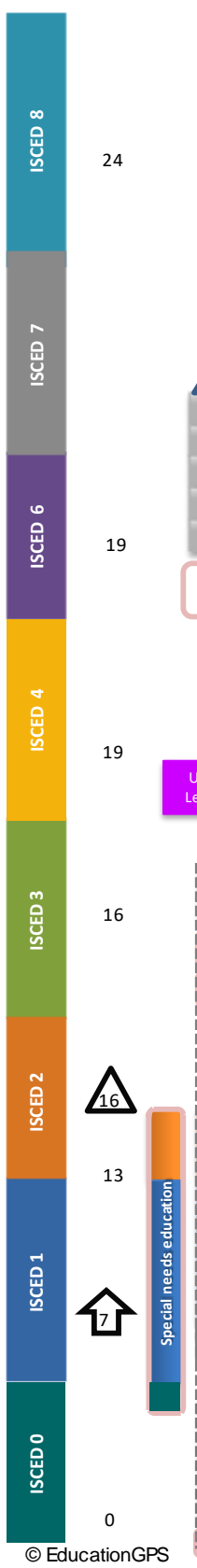

* See PDF version/Notes for more information on formal vocational education in Estonia

2018

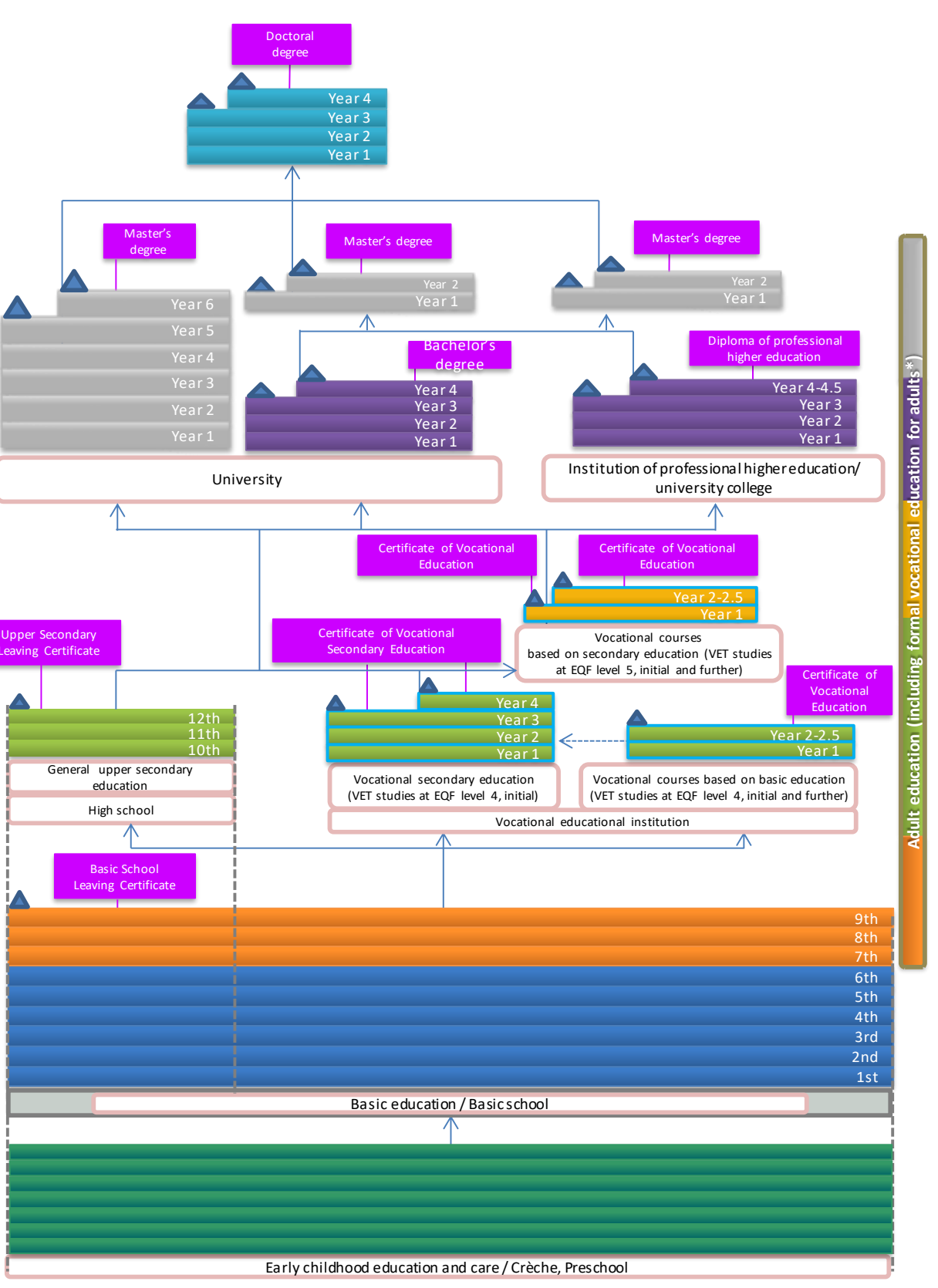

Note: The key for the interpretation of this table is available at the source link below.

Source: OECD (2019), "Estonia: Overview of the Education System", OECD Education GPS,

http://gpseducation.oecd.org/CountryProfile?primaryCountry=EST. 


\section{ANNEX B: STATISTICS}

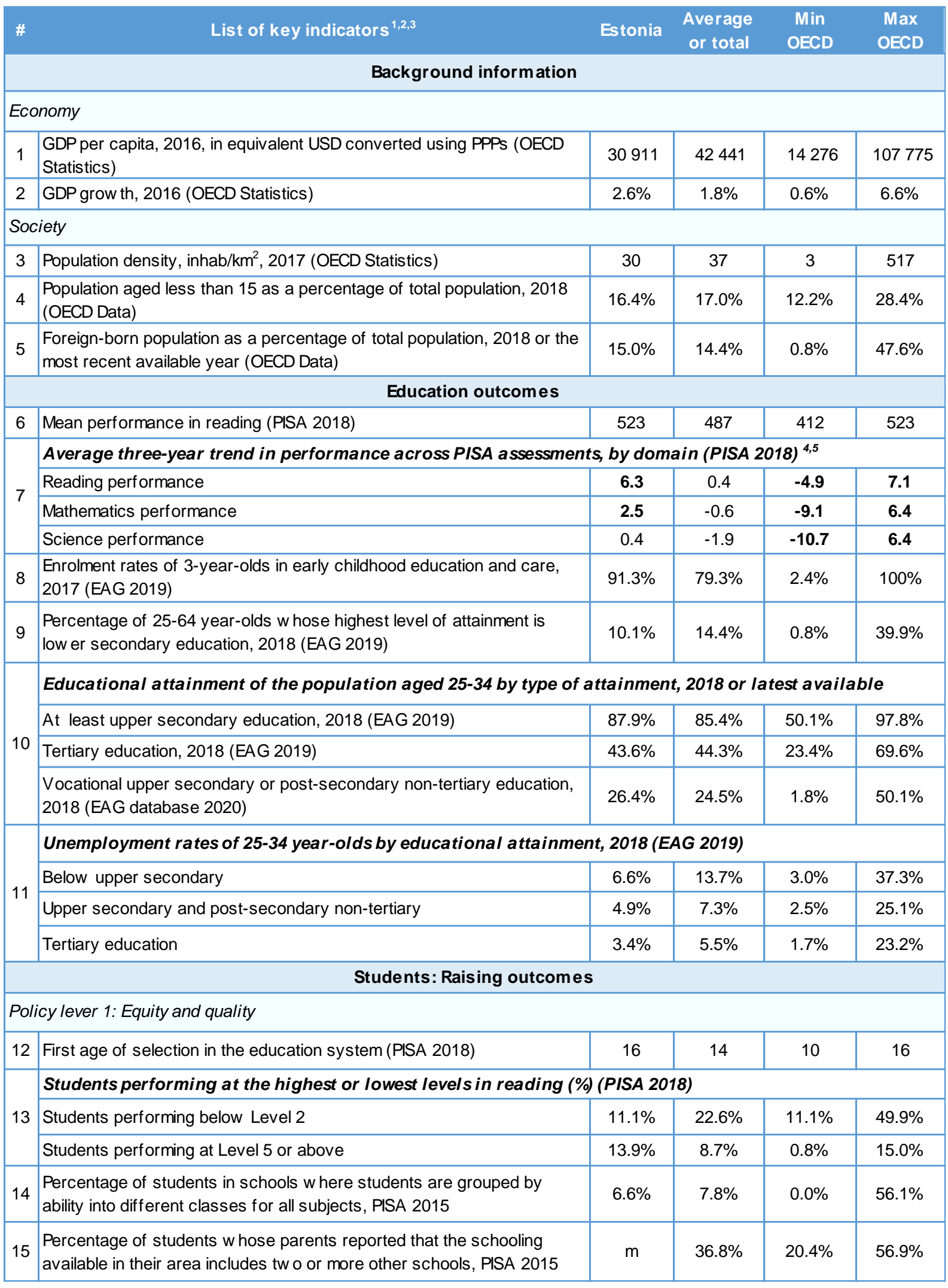




\begin{tabular}{|c|c|c|c|c|c|}
\hline$\#$ & List of key indicators ${ }^{1,2,3}$ & Estonia & $\begin{array}{l}\text { Average } \\
\text { or total }\end{array}$ & $\begin{array}{l}\text { Min } \\
\text { OECD }\end{array}$ & $\begin{array}{l}\text { Max } \\
\text { OECD }\end{array}$ \\
\hline 16 & $\begin{array}{l}\text { Percentage of students reporting that they have repeated at least a } \\
\text { grade in primary, low er secondary or upper secondary schools (PISA } \\
2015 \text { ) }\end{array}$ & $4.0 \%$ & $11.3 \%$ & $0.0 \%$ & $42.6 \%$ \\
\hline 17 & $\begin{array}{l}\text { Percentage of variance in reading performance in PISA test explained } \\
\text { by ESCS (PISA 2018) }\end{array}$ & $6.2 \%$ & $12.0 \%$ & $6.2 \%$ & $19.1 \%$ \\
\hline 18 & $\begin{array}{l}\text { Score difference in reading performance in PISA betw een non- } \\
\text { immigrant and immigrant students AFTER adjusting for socio-economic } \\
\text { status (PISA 2018) }\end{array}$ & -35 & -24 & -80 & 16 \\
\hline 19 & Score difference betw een girls and boys in reading (PISA 2018) ${ }^{4}$ & 31 & 30 & 10 & 52 \\
\hline \multicolumn{6}{|c|}{ Policy lever 2: Preparing students for the future } \\
\hline 20 & $\begin{array}{l}\text { Mean proficiency in literacy among adults aged } 16-64 \text { on a scale of } 500 \\
\text { (Survey of Adult Skills, PIAAC, 2012) }\end{array}$ & 275.9 & 267.7 & 220.1 & 296.2 \\
\hline 21 & $\begin{array}{l}\text { Difference in literacy scores betw een younger (25-34) and older (55- } \\
65) \text { adults AFTER accounting for age, gender, education, immigrant and } \\
\text { language background and parents' educational attainment (Survey of } \\
\text { Adult Skills, PIAAC, 2012). }\end{array}$ & 14.6 & 15.6 & -8.3 & 37.6 \\
\hline \multirow{4}{*}{22} & \multicolumn{5}{|l|}{ Share of students in upper secondary education in 2017 following: } \\
\hline & General programmes (OECD Stat - INES 2020) & $59.3 \%$ & $58.1 \%$ & $27.6 \%$ & $100.0 \%$ \\
\hline & Vocational programmes (OECD Stat - INES 2020) & $40.7 \%$ & $43.1 \%$ & $9.0 \%$ & $72.4 \%$ \\
\hline & Combined school and w ork-based programmes (OECD Stat - INES 2020) & $2.1 \%$ & $18.3 \%$ & $1.0 \%$ & $58.0 \%$ \\
\hline 23 & $\begin{array}{l}\text { First-time graduation rates from tertiary education, } 2017 \text { (Below the age } \\
\text { of } 30 \text {, excluding mobile students / OECD Stat - INES 2020) }\end{array}$ & $\mathrm{m}$ & $36.6 \%$ & $10.1 \%$ & $49.9 \%$ \\
\hline 24 & $\begin{array}{l}\text { Percentage of } 18-24 \text { year-olds not in education, employment or training, } \\
2018 \text { (EAG 2019) }\end{array}$ & $11.2 \%$ & $14.3 \%$ & $5.9 \%$ & $29.8 \%$ \\
\hline \multicolumn{6}{|c|}{ Institutions: Im proving schools } \\
\hline \multicolumn{6}{|c|}{ Policy lever 3: School improvement } \\
\hline \multirow{4}{*}{25} & \multicolumn{5}{|l|}{ The Learning Environment - PISA 2018} \\
\hline & Mean index of teacher support in language-of-instruction lessons & -0.11 & 0.01 & -0.61 & 0.47 \\
\hline & Mean index of disciplinary climate & 0.20 & 0.04 & -0.34 & 1.07 \\
\hline & Mean index of students' sense of belonging & -0.13 & 0.00 & -0.28 & 0.46 \\
\hline 26 & $\begin{array}{l}\text { Percentage of teachers in low er secondary education aged } 50 \text { years } \\
\text { old or more, } 2017 \text { (EAG 2019) }\end{array}$ & $53.9 \%$ & $37.0 \%$ & $6.3 \%$ & $54.2 \%$ \\
\hline \multirow{3}{*}{27} & \multicolumn{5}{|c|}{ Number of teaching hours per year in public institutions by education level, 2018 (EAG 2019) ${ }^{7}$} \\
\hline & Primary education & 585 & 783 & 561 & 1063 \\
\hline & Low er secondary education, general programmes & 602 & 709 & 481 & 1063 \\
\hline 28 & $\begin{array}{l}\text { Ratio of actual teachers' salaries to earnings for full-time, full-year adult } \\
\text { w orkers w ith tertiary education, low er secondary education, general } \\
\text { programmes, } 2016 \text { (EAG 2019) }\end{array}$ & 0.91 & 0.88 & 0.64 & 1.40 \\
\hline 29 & $\begin{array}{l}\text { Proportion of teachers w ho believe the teaching profession is valued in } \\
\text { society (TALIS 2018) }\end{array}$ & $26.4 \%$ & $25.8 \%$ & $4.5 \%$ & $67.0 \%$ \\
\hline 30 & $\begin{array}{l}\text { Proportion of teachers w ho w ould become a teacher again if they could } \\
\text { choose (TALIS 2018) }\end{array}$ & $74.1 \%$ & $75.6 \%$ & $54.9 \%$ & $92.2 \%$ \\
\hline
\end{tabular}




\begin{tabular}{|c|c|c|c|c|c|}
\hline$\#$ & List of key indicators ${ }^{1,2,3}$ & Estonia & \multirow[t]{2}{*}{$\begin{array}{l}\text { Average } \\
\text { or total }\end{array}$} & \multirow[t]{2}{*}{$\begin{array}{l}\text { Min } \\
\text { OECD }\end{array}$} & \multirow[t]{2}{*}{$\begin{array}{l}\text { Max } \\
\text { OECD }\end{array}$} \\
\hline \multicolumn{3}{|c|}{ Policy lever 4: Evaluation and assessment to improve student outcomes } & & & \\
\hline \multirow{3}{*}{31} & \multicolumn{5}{|c|}{$\begin{array}{l}\text { Percentage of students in schools where the following arrangements aimed at quality assurance and } \\
\text { improvement at school are used (PISA 2015): }\end{array}$} \\
\hline & Internal/Self-evaluation & $99.8 \%$ & $93.2 \%$ & $74.8 \%$ & $100.0 \%$ \\
\hline & External evaluation & $90.8 \%$ & $74.6 \%$ & $20.8 \%$ & $97.4 \%$ \\
\hline \multirow{5}{*}{32} & \multicolumn{5}{|c|}{$\begin{array}{l}\text { Percentage of students whose school principals reported that standardised tests are used for the } \\
\text { following purposes (PISA 2015): }\end{array}$} \\
\hline & To make decisions about students' retention or promotion & $34.0 \%$ & $31.3 \%$ & $3.4 \%$ & $60.6 \%$ \\
\hline & To monitor the school's progress from year to year & $72.7 \%$ & $69.4 \%$ & $26.2 \%$ & $97.7 \%$ \\
\hline & To make judgements about teachers' effectiveness & $49.9 \%$ & $37.0 \%$ & $4.4 \%$ & $87.5 \%$ \\
\hline & $\begin{array}{l}\text { To identify aspects of instruction or the curriculum that could be } \\
\text { improved }\end{array}$ & $60.5 \%$ & $58.9 \%$ & $14.1 \%$ & $92.4 \%$ \\
\hline 33 & $\begin{array}{l}\text { Percentage of low er secondary teachers } w \text { hose principals report } \\
\text { conducting formal appraisal of their teachers at least once per year } \\
\text { (TALIS 2018) }\end{array}$ & $80.1 \%$ & $63.5 \%$ & $16.2 \%$ & $98.1 \%$ \\
\hline \multicolumn{6}{|c|}{ Systems: Organising the system } \\
\hline \multicolumn{6}{|c|}{ Policy lever 5: Governance } \\
\hline \multirow{7}{*}{34} & \multicolumn{5}{|c|}{$\begin{array}{l}\text { Percentage of decisions taken at each level of government in public lower secondary education, } 2017 \\
\text { (EAG 2018) }\end{array}$} \\
\hline & Central & $0.0 \%$ & $23.8 \%$ & $0.0 \%$ & $83.3 \%$ \\
\hline & State & $0.0 \%$ & $10.3 \%$ & $0.0 \%$ & $62.5 \%$ \\
\hline & Regional/Sub-regional & $0.0 \%$ & $4.9 \%$ & $0.0 \%$ & $33.3 \%$ \\
\hline & Local & $12.5 \%$ & $13.3 \%$ & $0.0 \%$ & $71.9 \%$ \\
\hline & School & $58.3 \%$ & $34.0 \%$ & $0.0 \%$ & $91.7 \%$ \\
\hline & Multiple levels & $29.2 \%$ & $13.8 \%$ & $0.0 \%$ & $100.0 \%$ \\
\hline \multicolumn{6}{|c|}{ Policy lever 6: Funding } \\
\hline 35 & $\begin{array}{l}\text { Expenditure on education as a percentage of GDP (from primary to } \\
\text { tertiary), } 2016 \text { (EAG 2019) }\end{array}$ & $4.4 \%$ & $5.0 \%$ & $0.0 \%$ & $6.5 \%$ \\
\hline \multirow{6}{*}{36} & \multicolumn{5}{|c|}{$\begin{array}{l}\text { Annual expenditure per student by educational institutions, for all services, in equivalent USD converted } \\
\text { using PPPs for GDP, } 2016 \text { (EAG 2019) }\end{array}$} \\
\hline & Pre-primary education & 7146 & 8349 & 1579 & 17533 \\
\hline & Primary education & 6872 & 8470 & 2961 & 17913 \\
\hline & Low er secondary education & 7047 & 9884 & 2561 & 21739 \\
\hline & Upper secondary education & 6742 & 10368 & 3001 & 21231 \\
\hline & Tertiary education & 12909 & 15556 & 5787 & 48407 \\
\hline \multirow{3}{*}{37} & \multicolumn{5}{|c|}{ Relative proportions of public and private expenditure on educational institutions, 2016 (EAG 2019) } \\
\hline & Public sources & $88.7 \%$ & $82.7 \%$ & $62.7 \%$ & $97.6 \%$ \\
\hline & All private sources (includes international sources) & $11.3 \%$ & $17.4 \%$ & $2.4 \%$ & $37.3 \%$ \\
\hline \multirow{3}{*}{38} & \multicolumn{5}{|c|}{$\begin{array}{l}\text { Change in the share of expenditure on educational institutions, EAG } 2019 \text { (Percentage-point difference } \\
\text { between } 2010 \text { and 2016, primary to tertiary education) }\end{array}$} \\
\hline & Public sources & -0.4 & -2.7 & -9.8 & 6.3 \\
\hline & All private sources & 1.5 & 2.5 & -6.3 & 7.0 \\
\hline \multicolumn{6}{|c|}{$\begin{array}{l}\text { Notes } \\
\text { 1. The average, total, minimums and maximums refer to OECD countries except in the Survey of Adult Skills, where they refer to participating countries. For indicators } 6 \text {, } \\
13 \text { and } 17-19 \text { the average value refers to the arithmetic mean across all OECD member countries (and Colombia), excluding Spain. For indicator } 5 \text {, the average value refers } \\
\text { to the arithmetic mean across all OECD member countries (except Japan, Korea and Poland) as calculated by the Education Policy Outlook. } \\
\text { 2. "m": included when data is not available. } \\
\text { 3. "NP": included if the country is not participating in the study. } \\
\text { 4. Statistically significant values of the indicator are shown in bold (PISA only). } \\
\text { 5. The average three year trend is the average change in PISA score points from a country's/economy's earliest participation in PISA to PISA } 2018 . \\
\text { 6. "a": included when the category is not applicable. } \\
\text { 7. For Estonia, this refers to typical teaching time (teaching time required from most teachers when no specific circumstances apply to teachers). }\end{array}$} \\
\hline
\end{tabular}




\section{REFERENCES AND FURTHER READING}

Education Nation (2019), Estonia. For the SmartEST People in the World, Education Nation, Tallinn, https://www.innove.ee/wpcontent/uploads/2019/12/EducationNation Estonia ENGLISH.pdf.

EKKA (n.d.), "Assessing the quality of vocational training", Home - Vocational Training, EKKA, webpage, https://ekka.archimedes.ee/kutseoppe-kvaliteedi-hindamine/ (accessed 11 June 2020).

Ekool AS (n.d.), "About Ekool", About Ekool, Ekool AS, webpage, https://ekool.eu/index en.html (accessed 11 June 2020).

E-koolikott (n.d.), "E-Schoolbag”, Home, E-koolikot, webpage https://e-koolikott.ee/ (accessed 11 June 2020).

ENQA (2013), Panel Report of the External Review of Estonian Higher Education Quality Agency (EKKA), ENQA, Etterbeek, https://ekka.archimedes.ee/wp-content/uploads/Final report EKKA 2013-03-20.pdf.

EQA (Estonian Qualifications Authority) (n.d.), "Qualifications Framework”, EQA, webpage, https://www.kutsekoda.ee/kvalifikatsiooniraamistik/ (accessed 11 June 2020).

EQA (n.d.), "Qualifications Framework”, EQA, webpage, https://www.kutsekoda.ee/kvalifikatsiooniraamistik/ (accessed 11 June 2020).

EC (European Commission) (2020), Country Report: Estonia 2020, Commission Staff Working Document, EC, Brussels, https://eurlex.europa.eu/legal-content/EN/TXT/PDF/?uri=CELEX:52020SC0505\&from=EN.

EC (2019), Council Recommendation on the 2019 National Reform Programme of Estonia and delivering a Council opinion on the 2019 Stability Programme of Estonia, COM(2019) 506 final, EC, Brussels, https://eur-lex.europa.eu/legalcontent/EN/TXT/PDF/?uri=CELEX:52019DC0506\&from=EN.

EC (2019), Country Report: Estonia 2019, Commission Staff Working Document, EC, Brussels, https://ec.europa.eu/info/sites/info/files/file import/2019-european-semester-country-report-estonia en.pdf.

EC (2019), "Estonia", Education and Training Monitor 2019: Country Analysis, Publications Office of the European Union, Luxembourg, https://ec.europa.eu/education/resources-and-tools/document-library/education-and-training-monitor-2019estonia-report en

EC (2018), "Estonia", Education and Training Monitor 2018: Country Analysis, Publications Office of the European Union, Luxembourg, https://ec.europa.eu/education/sites/education/files/document-library-docs/et-monitor-report-2018estonia en.pdf.

EC (2010), Europe 2020: A European Strategy for Smart, Sustainable and Inclusive Growth, EC, Brussels, https://ec.europa.eu/eu2020/pdf/COMPLET\%20EN\%20BARROSO $\% 20 \% 20 \% 20007 \% 20-\% 20$ Europe\%202020\%20-\%20EN \%20version.pdf.

EC/EACEA/Eurydice (2020), "Ongoing Reforms and Policy Developments", Eurydice - Estonia, Eurydice, webpage https://eacea.ec.europa.eu/national-policies/eurydice/content/ongoing-reforms-and-policy-developments-20 en (accessed 08 June 2020).

Haaristo, H. S. et al. (2019). Mid-term Evaluation of Lifelong Learning Strategy, Praxis/Center for Applied Research, Tallinn, https://www.hm.ee/sites/default/files/2.elukestva oppe strateegia vahehindamise luhikokkuvote.pdf.

HITSA (Information Technology Foundation for Education) (2020), "First experiences: 10 recommendations from HITSA and educational technologists", Home - News, 22 March 2020, HITSA, webpage, https://www.hitsa.ee/uudised-1/hitsaharidustehnoloogid-soovitavad-1-nadal (accessed 11 June 2020).

Leppik, M (2019), Labour Market Success of Vocational and Higher Education Graduates: Summary and Main Conclusions, Ministry of Education and Research, Tartu, https://www.hm.ee/sites/default/files/ labour market success of graduates-summary.pdf.

Innove (n.d.), "Immersion", Home - Study materials and Methodologies, Innove Foundation Estonia, webpage, https://www.innove.ee/oppevara-ja-metoodikad/keelekumblus/ (accessed 11 June 2020).

Innove (n.d.), "Educational Counselling in Rajaleidja Centres", Home - Educational Counselling in Rajaleidja Centres, Innove Foundation Estonia, webpage, https://www.innove.ee/en/rajaleidja-network/ (accessed 11 June 2020).

Innove (n.d.), "Examinations and Tests", Home - Examinations and Tests, Innove Foundation Estonia, webpage, https://www.innove.ee/en/examinations-and-tests/ (accessed 11 June 2020).

Innove (2019), "Satisfaction of general education schools in 2019 and feedback on school environment surveys", ResearchSatisfaction and School Environment Surveys, Innove Foundation Estonia, webpage, https://www.innove.ee/uuringud/rahulolu/rahulolukusitlus-uldhariduses/ (accessed 11 June 2020).

MER (Ministry of Education and Research) (2020), "The Cabinet of Ministers has decided to transfer educational institutions to distance learning due to the risk of infection", Home - News, 13 March 2020, MER, webpage, https://www.hm.ee/et/uudised/valitsuskabinet-otsustas-viia-nakkusohu-tottu-haridusasutused-distantsoppele (accessed 11 June 2020). 


\section{8 | No. 13 - EDUCATION POLICY OUTLOOK IN ESTONIA}

MER (2020), "Supporting students with special educational needs: study organization and support services", Home - Activities, MER, webpage, https://www.hm.ee/et/tegevused/hariduslike-erivajadustega-opilaste-toetamine-oppekorraldus-ja-tugiteenused (accessed 11 June 2020).

MER (2020), "Weekly live lessons will start on Thursday”, Home - news, MER, webpage, https://www.hm.ee/et/uudised/neljapaevalalgavad-iganadalased-live-koolitunnid-oppimisest-ja-opetamisest (accessed 11 June 2020).

MER (2020), "Satisfaction with education", Home - Satisfaction with Education, MER, webpage, https://www.hm.ee/en/satisfactioneducation (accessed 11 June 2020).

MER (2020), "Working groups", Home - Involvement and Participation - Strategic Planning for 2021-2035, MER, webpage, https://www.hm.ee/et/kaasamine-osalemine/strateegiline-planeerimine-aastateks-2021-2035/tooruhmad (accessed 11 June 2020).

MER (2020), "Giving an invitation", Activities - Teacher and School Leader, MER, webpage, https://www.hm.ee/et/tegevused/opetajaja-koolijuht/kutse-andmine (accessed 11 June 2020).

MER (2020), PISA English Summary, MER, Tartu, https://www.hm.ee/sites/default/files/ pisa 2018 english summary ed.pdf.

MER (2019), Smart and Active Estonia 2020: Summary of the vision documents of three expert groups, MER, Tartu, https://www.hm.ee/sites/default/files/tark ja tegus eng a43mm.pdf.

MER (2019), Important Activities in the 2019/2020 Academic Year, MER, Tartu, https://www.hm.ee/sites/default/files/htm koolialgusepakett a4 eng.pdf.

MER (2019), Summary of the Ministry of Education and Research's Annual Report for 2018, MER, Tartu, https://www.hm.ee/sites/defaultffiles/htm aruanne 2018 en.pdf.

MER (2019), "School network program", Home - School Network Programme, MER, webpage, https://www.hm.ee/et/koolivorguprogramm (accessed 11 June 2020)

MER (2019), "Teachers and school leaders", Activities - Teacher and School Leader, MER, webpage, https://www.hm.ee/et/tegevused/opetaja-ia-koolijuht (accessed 11 June 2020).

MER (2018), "Apprenticeship", Activities - Vocational Education, MER, webpage, https://www.hm.ee/et/opipoiss (accessed 11 June 2020).

MER (2016), "Training and development activities", Activities - Teacher and School Leader, MER, webpage, https://www.hm.ee/et/tegevused/opetaja-ja-koolijuht/koolitus-ja-arendustegevus (accessed 11 June 2020).

Ministry of Culture (2014), Integrating Estonia 2020, Estonian Ministry of Culture, Tallinn, https://www.kul.ee/sites/kulminn/files/23748 en proofreading le2020 eng.pdf.

Musset, P. et al. (2019), Vocational Education and Training in Estonia, OECD Reviews of Vocational Education and Training, OECD Publishing, Paris, https://doi.org/10.1787/g2g9fac9-en.

OECD (2020), "How Estonia is delivering online career guidance during the coronavirus crisis", OECD Education and Skills Today, OECD, webpage, https://oecdedutoday.com/estonia-online-career-guidance-during-coronavirus-crisis/ (accessed 11 June 2020).

OECD (2020), Early Learning and Child Well-being in Estonia, OECD Publishing, Paris, https://doi.org/10.1787/15009dbe-en.

OECD (2020), Foreign-born population (indicator), https://doi.org/10.1787/5a368e1b-en (accessed 20 April 2020).

OECD (2020), Young population (indicator), https://doi.org/10.1787/3d774f19-en (accessed 14 April 2020).

OECD (2020), PISA 2018 Results (Volume III): What School Life Means for Students' Lives, PISA, OECD Publishing, Paris, https://doi.org/10.1787/acd78851-en.

OECD (2020), TALIS 2018 Results (Volume II): Teachers and School Leaders as Valued Professionals, TALIS, OECD Publishing, Paris, https://doi.org/10.1787/19cf08df-en.

OECD (2020), Learning Remotely when Schools Close: How well are Students and Schools Prepared? Insights from PISA, OECD Policy Responses to Coronavirus (COVID-19), OECD Publishing, Paris, https://read. oecd-ilibrary.org/view/?ref=127 127063-iiwm328658\&title=Learning-remotely-when-schools-close.

OECD (2019), "Benchmarking Higher Education System Performance: Estonia", in Benchmarking Higher Education System Performance, OECD Publishing, Paris, https://doi.org/10.1787/615473ab-en.

OECD (2019), Education Policy Outlook 2019: Working Together to Help Students Achieve their Potential, OECD Publishing, Paris, https://doi.org/10.1787/2b8ad56e-en.

OECD (2019), Education at a Glance 2019: OECD Indicators, OECD Publishing, Paris, https://doi.org/10.1787/f8d7880d-en.

OECD (2019), OECD Economic Surveys: Estonia 2019, OECD Publishing, Paris, https://doi.org/10.1787/f221b253-en.

OECD (2019), "OECD Skills Strategy Dashboard", in OECD Skills Strategy 2019: Skills to Shape a Better Future, OECD Publishing, Paris, https://doi.org/10.1787/9feb5d74-en. 


\section{9 | No. 13 - EDUCATION POLICY OUTLOOK IN ESTONIA}

OECD (2019), TALIS 2018 Results (Volume I): Teachers and School Leaders as Lifelong Learners, TALIS, OECD Publishing, Paris, https://doi.org/10.1787/1d0bc92a-en.

OECD (2018), Education at a Glance 2018: OECD Indicators, OECD Publishing, Paris, https://doi.org/10.1787/eag-2018-en.

OECD (2018), Education Policy Outlook 2018: Putting Student Learning at the Centre, OECD Publishing, Paris, http://www.oecd.org/education/education-policy-outlook-2018-9789264301528-en.htm.

OECD (2017), OECD Economic Surveys: Estonia 2017, OECD Publishing, Paris, https://doi.org/10.1787/eco surveys-est-2017-en.

OECD (2017), PISA 2015 Results (Volume III): Students' Well-Being, OECD Publishing, Paris, http://dx.doi.org/10.1787/9789264273856-en.

OECD (2017), Starting Strong 2017: Key OECD Indicators on Early Childhood Education and Care, OECD Publishing, Paris, https://doi.org/10.1787/9789264276116-en.

OECD (2016), PISA 2015 Results (Volume I): Excellence and Equity in Education, OECD Publishing, Paris, http://dx.doi.org/10.1787/9789264266490-en.

OECD (2016), PISA 2015 Results (Volume II): Policies and Practices for Successful Schools, OECD Publishing, Paris, http://dx.doi.org/10.1787/9789264267510-en.

OECD (2016), Skills Matter: Further Results from the Survey of Adult Skills, OECD Skills Studies, OECD Publishing, Paris, https://doi.org/10.1787/9789264258051-en.

OECD (2015), Education Policy Outlook 2015: Making Reforms Happen, OECD Publishing, Paris. http://dx.doi.org/10.1787/9789264225442-en.

OECD (2015), OECD Economic Surveys: Estonia 2015, OECD Publishing, Paris, https://doi.org/10.1787/eco surveys-est-2015-en.

OECD (2014), TALIS 2013 Results: An International Perspective on Teaching and Learning, TALIS, OECD Publishing, Paris, http://dx.doi.org/10.1787/9789264196261-en.

OECD (2013), Synergies for Better Learning: An International Perspective on Evaluation and Assessment, OECD Reviews of Evaluation and Assessment in Education, OECD Publishing, Paris, http://dx.doi.org/10.1787/9789264190658-en.

OECD (2012), OECD Economic Surveys: Estonia 2012, OECD Publishing, Paris, https://doi.org/10.1787/eco surveys-est-2012-en.

OSKA (2018), The Estonian Labour Market Today and Tomorrow, OSKA, Tallinn, https://oska.kutsekoda.ee/wpcontent/uploads/2018/12/Eesti-t\%C3\%B6\%C3\%B6turg-t\%C3\%A4na-ja-homme-2018.pdf.

Opimekodus (n.d.), "Learning in the home: Estonian e-learning opportunities for adults in one place", Home, Opimekodus, webpage, https://opimekodus.ee/kontakt/ (accessed 11 June 2020).

Parliament of Estonia (2019), Vocational Educational Institutions Act, Parliament of Estonia, Tallinn, https://www.riigiteataja.ee/en/eli/505022014002/consolide/current (accessed 11 June 2020).

Parliament of Estonia (2018), Preschool Child Care Institutions Act, Parliament of Estonia, Tallinn, https://www.riigiteataja.ee/en/eli/520122013003/consolide/current (accessed 11 June 2020).

Parliament of Estonia (2015), Basic Schools and Upper Secondary Schools Act, Parliament of Estonia, Tallinn, https://www.riigiteataja.ee/en/eli/ee/508012015002/consolide (accessed 11 June 2020).

Parliament of Estonia (2015), Professions Act, Parliament of Estonia, Tallinn, https://www.riigiteataja.ee/en/eli/523022015001/consolide (accessed 11 June 2020).

Parliament of Estonia (2015), Adult Education Act, Parliament of Estonia, Tallinn, https://www.riigiteataja.ee/en/eli/529062015007/consolide (accessed 11 June 2020).

SAIS (Estonian Admissions Information System) (2020), "Applications received", Public Information - Applications Received, SAIS, webpage, https://sais.ee/PublicInfo/ApplicationStats.

Santiago, P., et al. (2016), OECD Reviews of School Resources: Estonia 2016, OECD Reviews of School Resources, OECD Publishing, Paris, https://doi.org/10.1787/9789264251731-en (accessed 11 June 2020).

Taguma, M., I. Litjens and K. Makowiecki (2012), Quality Matters in Early Childhood Education and Care: Portugal 2012, Quality Matters in Early Childhood Education and Care, OECD Publishing, Paris, https://doi.org/10.1787/9789264176720-en.

Vandenbroeck, M., K. Lenaerts and M. Beblavý (2018), Benefits of Early Childhood Education and Care and the Conditions for Obtaining Them, Publications Office of the European Union, Luxembourg, http://dx.doi.org/10.2766/20810. 
30 | No. 13 - EDUCATION POLICY OUTLOOK IN ESTONIA

\section{NOTES}

1 On 25 May 2018, the OECD Council invited Colombia to become a Member. While Colombia is included in the OECD averages reported in this publication for data from Education at a Glance, the Programme for International Student Assessment and the Teaching and Learning International Survey, at the time of preparation of these OECD datasets, Colombia was in the process of completing its domestic procedures for ratification and the deposit of Colombia's instrument of accession to the OECD Convention was pending.

2 In 2017, the population of Estonia was comprised by around $70 \%$ of Estonian speakers, around $25 \%$ of Russian speakers, and the remaining $5 \%$ were other groups such as Ukrainian, Finnish and Latvian speakers.

This paper is published under the responsibility of the Secretary-General of the OECD. The opinions expressed and arguments employed herein do not necessarily reflect the official views of OECD member countries or the European Union.

This document and any map included herein are without prejudice to the status of or sovereignty over any territory, to the delimitation of international frontiers and boundaries and to the name of any territory, city or area.

Photo credits: Cover (C) Shutterstock/Sasha Chebotarev

(C) OECD 2020

The use of this work, whether digital or print, is governed by the Terms and Conditions to be found at: http://www.oecd.org/termsandconditions. 
This document has also been published as:

OECD (2020), Education Policy Outlook: Estonia, available at: www.oecd.org/education/policy-outlook/country-profile-Estonia-2020.pdf

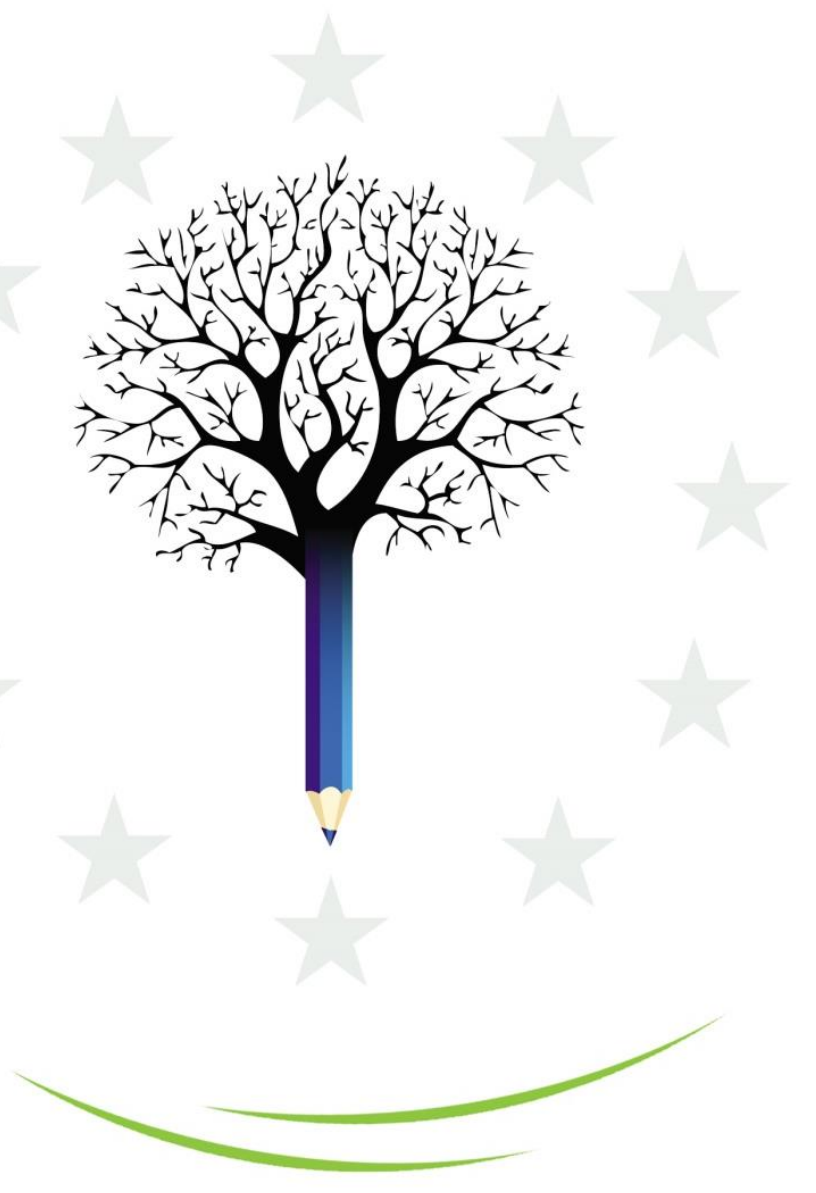

www.oecd.org/edu/policyoutlook.htm
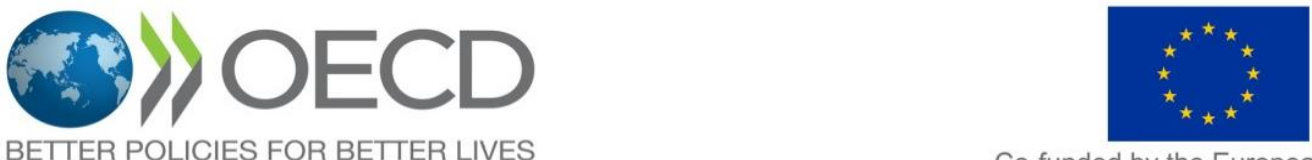